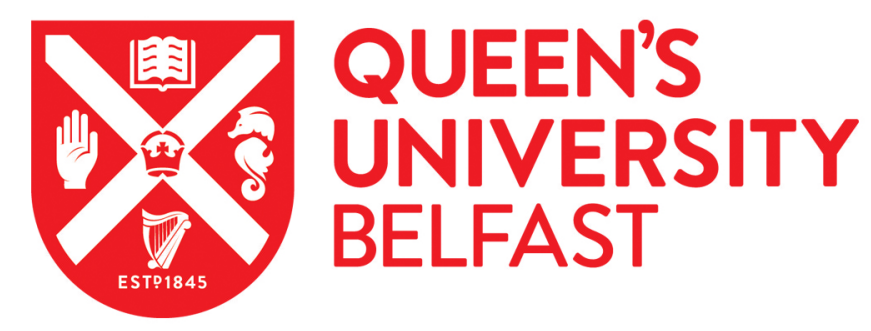

\title{
Representation of the People: Franchise Extension and The 'Sinn Féin Election' in Ireland, 1918
}

de Bromhead, A., Fernihough, A., \& Hargaden, E. (2020). Representation of the People: Franchise Extension and The 'Sinn Féin Election' in Ireland, 1918. The Journal of Economic History, 80(3), 886-925.

https://doi.org/10.1017/S0022050720000376

\section{Published in:}

The Journal of Economic History

\section{Document Version:}

Peer reviewed version

Queen's University Belfast - Research Portal:

Link to publication record in Queen's University Belfast Research Portal

\section{Publisher rights}

(c) The Economic History Association 2020.

This work is made available online in accordance with the publisher's policies. Please refer to any applicable terms of use of the publisher.

\section{General rights}

Copyright for the publications made accessible via the Queen's University Belfast Research Portal is retained by the author(s) and / or other copyright owners and it is a condition of accessing these publications that users recognise and abide by the legal requirements associated with these rights.

Take down policy

The Research Portal is Queen's institutional repository that provides access to Queen's research output. Every effort has been made to ensure that content in the Research Portal does not infringe any person's rights, or applicable UK laws. If you discover content in the Research Portal that you believe breaches copyright or violates any law, please contact openaccess@qub.ac.uk. 
REPRESENTATION OF THE PEOPLE: FRANCHISE EXTENSION AND

THE ‘SINN FÉIN ELECTION’ IN IRELAND, 1918

\begin{abstract}
Do large franchise extensions bring about dramatic electoral changes? Electoral reforms in 1918 nearly tripled the number of people eligible to vote in Ireland. Following the reforms - the largest franchise extension in UK history - the previously obscure Sinn Féin party secured 73 of Ireland's 105 seats, an outcome that precipitated a guerrilla war and ultimately independence from the United Kingdom. However, our analysis finds little evidence that the franchise reforms benefited Sinn Féin. New female electors appear less likely to have supported Sinn Féin while new male electors were no more likely to vote for Sinn Féin than the existing electorate. Women also appear less likely to have cast a vote at all. Economic and social factors did matter when it came to voting however, as did public opinion in relation to armed rebellion. These results remind us that dramatic political changes, such as those that took place in Ireland 1918, do not require dramatic changes in political participation. Sinn Féin’s electoral success was more likely driven by a change of heart on behalf of the Irish electorate, rather than a change in its composition.
\end{abstract}




\section{Introduction}

Do large franchise extensions bring about dramatic electoral changes? In this paper we examine the relationship between major franchise reform and one of the most important political events in British and Irish history: the 1918 General Election in Ireland.

In early 1918, towards the end of World War One, the United Kingdom extended its electoral franchise. All men over the age of 21 and most women over the age of 30 were now entitled to vote, a right previously reserved for adult male householders. Ireland, at the time still part of the United Kingdom, saw its electorate grow from under 700,000 to over 1.9 million.

The 1918 Election in Ireland also saw a relatively new party, Sinn Féin, contest a general election for the first time. Founded in 1905 but operating at a small scale for the first decade of their existence, by 1918 Sinn Féin were a radical republican, pro-independence party (Sinn Féin means “Ourselves” in Irish). Its leadership was closely (and openly) aligned with the armed paramilitary group that would come to be known as the Irish Republican Army (IRA). The party's intent was clear: withdrawal from the British Parliament, the establishment of an Irish Republic, and a promise to use "any and every means available” to do so (Sinn Féin, 1918). Sinn Féin's revolutionary streak contrasted with the moderately conservative Irish Parliamentary Party (IPP), who were steadfastly committed to constitutional nationalist politics.

The result was a landslide victory for Sinn Féin. The IPP, the dominant party for decades, were decimated. Though they had not even contested the prior election, Sinn Féin won 73 out of 105 seats in Ireland. Within two months, Sinn Féin’s MPs had declared independence from the UK and the armed conflict that would become Ireland's War of Independence began.

As the "Sinn Féin Election" immediately followed franchise extension, it is tempting to attribute a principal role to the franchise extension in the party's electoral victory. But were the 
newly enfranchised voters the same people who supported dramatic political upheaval? This paper quantitatively assesses how changes in voting rights shaped the outcome of the election. Perhaps surprisingly, we find that changes in voting rights cannot explain the Sinn Féin victory. Our results indicate that constituencies with greater numbers of newly enfranchised electors, all else being equal, did not return a higher Sinn Féin vote share. In fact, in constituencies where the share of female electors was higher, support for Sinn Féin was lower.

If not the expansion of the franchise, what then could explain the remarkable rise of Sinn Féin? Could it be that traditional socioeconomic factors have more explanatory power, or perhaps it was the effect the "Easter Rising” of 1916 had on public opinion? ${ }^{1}$ In this paper, we consider franchise changes in conjunction with several alternative hypotheses. These hypotheses explore economic factors, such as occupation and wealth, public opinion relating to events between 1916 and 1918 as well as long run factors, such as the impact of the Great Famine, details of which we set out in subsequent sections.

Under these alternative hypotheses, the franchise extension was not a substantial cause of the electoral shift, and variables such as the number of new electors should not have a significant effect on the Sinn Féin vote. We consider both the relationship between these categories and the decision to vote for Sinn Féin, and also the decision to cast a vote at all. We find that all of the alternative hypotheses have some explanatory role, with varying importance. The franchise extension explains about one-tenth of the overall variation in Sinn Féin vote share. For context, the economic hypothesis/category explains about twice that. Based on this evidence, we conclude that franchise changes did not drive the Sinn Féin victory in 1918.

\footnotetext{
${ }^{1}$ The Easter Rising was an armed insurgency against British rule that started on Easter Monday in 1916. The Rising was a military failure but is seen as a pivotal moment in Irish history due to its impact on public opinion. Many of the 1918 Sinn Féin leadership had participated in the Easter Rising.
} 
That changes in voting rights can have implications for political outcomes in some contexts is well recognised. Related work has previously examined the effects of franchise extensions, inter alia, on stock markets (Lehmann-Hasemeyer et al. 2014), on health expenditures (Aidt et al. 2010; Fujiwara, 2015), and on the political budget cycle (Aidt and Mooney, 2014). These papers highlight that the enfranchisement of poorer voters is often associated with higher welfare spending. ${ }^{2}$ Greater female political participation has been linked to areas as disparate as international trade and social policy (inter alia de Bromhead, 2017; Miller, 2008, Aidt and Dallal, 2008; Lott and Kenny, 1999, Voucharas and Xefteris, 2018). The question of how universal franchise affected the growth of social democracy and the nationalisation of politics has been raised more broadly (Caramani, 2004 p.249; Polanyi, 1944). Our paper highlights the context specific nature of franchise extension as a catalyst for economic, social and political change.

Drawing a link between franchise extension and political change is particularly tempting in the context of Ireland in 1918 because the franchise extension was so large, and the apparent implications (violent rebellion) were so significant. Furthermore, and perhaps lost in the context of the political violence, the economic consequences of the election result were also substantial. Consistent with radical nationalism, economic self-sufficiency had been a central tenet of Sinn Féin policy from its foundation (Neary, 1984). Once ultimately in power, Éamon de Valera, leader of Sinn Féin in 1918, would go on to adopt a policy of economic nationalism in the newly independent Ireland. This policy arguably held back Irish economic development for decades (Honohan and Walsh, 2002).

The analysis in this paper was made possible by our digitisation of census records and other historical data. Our empirical approach links electoral results with demographic data from the

\footnotetext{
${ }^{2}$ Aidt et al. (2010) however find evidence of a "u-shaped” relationship between franchise extension and spending.
} 
1911 census at the constituency level for the entire country. This permits us to analyse the effects not just of franchise extension itself like Berlinski and Dewan (2011), but also control for a rich set of constituency-level factors like literacy rates, occupation, and religious affiliation. We go further and collect data relating to the alternative hypotheses of the rise of Sinn Féin, ranging from economic and long-run factors, such as the impact of the Great Famine, to the radicalisation of the Irish electorate by the events of 1916-18, to the characteristics of the candidates themselves. In addition to the natural focus on Sinn Féin, we also examine the relationships for votes for the IPP and the Unionist Party, the other major political parties of the period. Our analysis indicates that Sinn Féin did not benefit from the extension of the franchise in 1918, and may have even fared better had women not been enfranchised. We conclude that a widespread change in public opinion, most likely brought about by the revolutionary uprising in 1916 and the British attempts to conscript Irish men into wartime military service, and indeed the British reaction to these events, are crucial to understanding the Sinn Féin victory in $1918 .{ }^{3}$ Finally we examine the factors associated with turnout in the election and find that new female voters and turnout rates were negatively associated, perhaps accounting for a muted effect of women's enfranchisement.

Our paper makes a number of contributions. Firstly, we quantitatively address a long-standing question in Irish history and find that franchise extension does not explain the Sinn Féin victory in 1918. Secondly, we provide evidence that the events between the Easter Rising of 1916 and the General Election in 1918 (such as deportation of participants and donations to the 1916 veterans’ fund) were associated with support for Sinn Féin. Thirdly, our research connects to a wider literature on the impact of franchise extension on politics and policy. Fourthly, we make a contribution by assembling a dataset at constituency level that brings together a number of

\footnotetext{
${ }^{3}$ Irish public opinion was so strongly opposed to British efforts of conscription that this episode is popularly referred to as the 'Conscription Crisis'.
} 
variables that are important to understanding a pivotal moment in Irish and British history, events which are the focus of considerable public interest in the midst of Ireland's 'Decade of Centenaries'. ${ }^{4}$ Finally, our research explores the broad question of how economic, demographic and social aspects drive radical political change. We emphasize that franchise extension alone need not result in substantial shifts in electoral politics.

The paper will proceed as follows: the next section provides some important historical and political background to the period, outlining the rise of Sinn Féin as a political force and the social and political context in which the election of 1918 took place. Section 3 describes the electoral, socioeconomic and other data employed in our empirical analysis of section 4, while the robustness of our results is tested in section 5. Finally section 6 outlines some general conclusions.

\section{Background}

\section{Historical Context}

The Sinn Féin victory in 1918 was a remarkable result for a party that had never before contested a general election. ${ }^{5}$ Founded in 1905 , until the revolutionary events of 1916-1918 Sinn Féin were a marginal political movement and "a mere nationalist faction” (Lee, 1989, p. 8). By 1918 however the party was a major political force, winning 73 of the 105 Irish parliamentary seats with the estimated support of between 52-64\% of voters (Coakley, 1994 pp.163-64). ${ }^{6}$

\footnotetext{
${ }^{4}$ An official Irish government programme of commemoration events, accompanied by a joint statement of the UK and Irish governments are available https:/www.decadeofcentenaries.com/

${ }^{5}$ Although the party contested some by-elections in the years following its founding, it did not contest either of the parliamentary elections held in 1910 (Laffan, 2005).

${ }^{6}$ Sinn Féin won $47 \%$ of votes cast but were uncontested in 25 constituencies. Assuming turnout and support were similar in uncontested and contested districts gives an estimate of 51.5\%, assuming all votes went to Sinn Féin in uncontested areas yields a figure of 64\%. Success however varied geographically, with Sinn Féin
} 
The collapse of the Irish Parliamentary Party (IPP) was perhaps as dramatic as the Sinn Féin victory. The IPP (and their rivals, the Unionists) had dominated Irish politics in the last decades of the $19^{\text {th }}$ century. The IPP achieved a comprehensive victory in the last pre-war election of December 1910, securing 73 of 103 Irish parliamentary seats, including 49 seats where the IPP candidate was elected unopposed. In contrast, they returned only six seats in 1918. Whether changes in the franchise can help us explain this dramatic electoral shift is the principal question of this paper. The unionist parties, who were defined by their opposition to Irish selfrule, secured twenty seats in 1910 and twenty-six seats in 1918, solidifying its position as the dominant party in the north of Ireland. ${ }^{7}$

Despite the IPP's electoral success in 1910, the eight years between general elections - the longest period without a general election in UK parliamentary history - had witnessed a marked shift in the political landscape. ${ }^{8}$ After the 1910 election, the IPP's reward for supporting the Liberal government was the Home Rule Bill of 1912. The Home Rule Bill, scheduled to come into force in 1914, provided limited self-government ("Home Rule”) for Ireland while remaining part of the United Kingdom. The Bill was opposed by Unionists, and the establishment of the Ulster Volunteers in 1913 indicated a willingness to resist its imposition by force. Nationalists responded by forming their own militia force, the Irish Volunteers. Ireland - and indeed the UK - was on the brink of civil war.

Home Rule was shelved when events on the European continent led to war breaking out in the late summer of 1914. The leaderships of both the Unionists and the IPP supported the war effort, with the IPP believing they would be rewarded once hostilities ceased (Miller, 1973). A minority within the nationalist movement - perhaps 12,000 of the 180,000 members of the Irish

\footnotetext{
winning 69 of the 72 seats in the majority Catholic south of Ireland, while only securing $19 \%$ of the votes cast in the six counties that would go on to constitute Northern Ireland.

${ }^{7}$ The Irish Unionist party won 22 seats with other unionist candidates winning 4 seats in 1918.

${ }^{8}$ Elections had been postponed with the outbreak of war in 1914.
} 
Volunteers - rejected the leadership’s position. This smaller group coalesced around the leaders of the clandestine revolutionary group, the Irish Republican Brotherhood (IRB). The IRB advocated the overthrow of British rule in Ireland by any means necessary, including violence (Wheatley, 2005). Its membership included Éamon de Valera, who would go on to lead Sinn Féin in the 1918 General Election.

\section{Shifting Public Opinion, 1916-1918}

With the British authorities preoccupied with the war on the continent, the insurgents saw their opportunity. ${ }^{9}$ In Easter week, 1916, they staged a rising in Dublin, occupying key buildings and proclaiming Irish independence in front of the General Post Office. The rising was quickly put down by the British authorities and fifteen of the leaders court-martialled and shot following the rebel surrender. Although the rising had failed militarily, the perceived severity of the British reaction in its aftermath bred discontent among many sections of the population and helped turn public opinion towards sympathy for the rebels (Laffan, 2005). Despite the fact that Sinn Féin had very little to do with the Rising directly, they capitalised on the shift in public opinion that occurred in its aftermath. ${ }^{10}$ This relationship between public opinion towards the 1916 Rising and electoral support for Sinn Féin will be tested as an important alternative hypothesis in the analysis that follows.

British attempts to introduce conscription in Ireland also boosted Sinn Féin's profile and further undermined the IPP's position as the preeminent force in Irish nationalist politics. Conscription had been enacted in Britain in 1916 and the German offensive of 1918 had induced the cabinet

\footnotetext{
${ }^{9}$ Only about 2,500 rebels took part in the Easter Rising, representing about 20\% of the Irish Volunteers in Ireland in 1916 (Collins, 2016). The volunteers that took part in the 1916 Rising were therefore a minority within a minority among those who had joined in 1913/14.

${ }^{10}$ The British and Irish press, as well as the public in general, inaccurately dubbed the rising the 'Sinn Féin' rebellion. (Henry, 1920). The IRB and Sinn Féin were distinct entities, but with considerable overlap in membership.
} 
to finally extend conscription to Ireland (Ward, 1974). The attempt to introduce conscription in Ireland was, not unexpectedly, deeply unpopular. The various disparate strings of Irish Nationalism were united in opposition, with the IPP even going as far as withdrawing from parliament in protest (Coakley, 1994). Despite this demonstration, the conscription issue reinforced the link between the IPP and the war effort while Sinn Féin claimed the role of the most vociferous opponent of conscription, declaring that the conscription bill was tantamount to a declaration of war on Ireland (Townshend, 2013). We will also attempt to evaluate the impact of the events of 1918 on public opinion towards Sinn Féin in our empirical analysis.

The fallout from the Easter Rising and the prospect of general conscription set the scene for Sinn Féin's first electoral successes. First in Roscommon in February 1917, followed by victories in Longford, Clare, Kilkenny, and Cavan, Sinn Féin gained seats in a series of byelections. However the IPP was able to defeat Sinn Féin in three by-elections in 1918, restoring some optimism to the party leadership (Laffan, 2005).

Nevertheless, the IPP had little success between 1910 and 1918. The constitutional approaches of the IPP ultimately failed to achieve even limited self-government for Ireland. This fuelled the idea that the party had taken parliamentary nationalism as far as it could, and that a new force was needed to carry on the struggle for Irish self-determination. The IPP election manifesto for 1918 pled for continuity rather than change, with reference to past achievements rather than future reforms (United Irish League \& IPP, 1918). ${ }^{11}$ Sinn Féin had positioned itself as a serious and determined alternative movement. The Sinn Féin manifesto of 1918 clearly sets out the party's aims: to withdraw representation from Westminster, establish an Irish assembly, to use "any and every means" to resist British power in Ireland, and to appeal to the Paris Peace Conference to recognise Ireland as an independent nation (Sinn Féin, 1918). The

\footnotetext{
${ }^{11}$ It is noteworthy that both the IPP and the Sinn Féin election manifestos are devoid of policy pledges beyond those relating to the issue of Irish nationalism.
} 
decision by the Irish Labour Party not to contest the election ensured the 1918 election represented a relatively clear cut choice between two different versions of Irish nationalism the incremental achievement of modest independence pursued by the IPP and the radical and revolutionary republicanism offered by Sinn Féin.

The Franchise Hypothesis: The Representation of the People Act (1918)

The choice between a continuation of the constitutional approach of the IPP and the radical republicanism of Sinn Féin was before an electorate that had expanded dramatically since 1910. The Representation of the People Act of 1918 emerged during the First World War, noting that the sacrifices made during the war should be acknowledged in the enfranchisement of the remaining disqualified men (Blackburn, 2011). Although there was a general consensus across political parties that universal suffrage should apply to men, the provisions granting women the vote were more contentious (Ogg, 1918). The final Act did not achieve universal suffrage, but did increase the UK electorate from eight to 21 million. All men over the age of 21 and women over 30 who met a property requirement would be entitled to vote

In Ireland, the Act resulted in a near tripling of the Irish electorate, from 698,000 to 1,931,000 (Laffan, 2005). The fact that many constituencies had not been contested for a number of decades and an eight-year gap between elections meant the electorate was inexperienced with voting. It is estimated that only 360,000 people-less than $20 \%$ of the electorate-had voted in a previous parliamentary election (Coakley, 1994). Many within the IPP worried that this new electorate would be easily radicalised and would not remember the political achievements of the party of the previous decades, most notably in the area of land reform (McConnel, 2004).

Historians have previously cited the franchise extension as a factor in understanding the Sinn Féin victory in 1918 (McConnel, 2004; Laffan, 2005; Coakley, 1994; Farrell, 1971), but its importance has not been subject to a rigorous quantitative assessment. Farrell (1971) drew 
perhaps the most concrete connection and argued that without the change in voting rights, the IPP would have been the victorious party in 1918. This contention has been challenged by Garvin (1981), who examined correlations between the Sinn Féin vote and aggregated demographic data for 18 counties, and found no correlation between support for Sinn Féin and the proportion of young people in 1911. Similarly, Fitzpatrick (1978) rejects the notion that Sinn Féin would have been defeated without franchise extension, emphasising that the party won five out of eight by-elections conducted under the old register in 1917 and 1918.

Our analysis goes further than previous studies such as Garvin (1981) in a number of ways. Firstly, we consider the relationship between the number of new male and female voters and support for Sinn Féin directly, rather than looking at the number of young people. Secondly, our analysis considers 70 constituency level results rather than 18 counties, allowing for greater identifying variation. Finally, we include a far greater number of control variables and consider alternative explanations for the success of Sinn Féin alongside that of franchise extension.

The impact of the changes to the parliamentary franchise in Ireland in 1918 must be viewed within a wider context. Following the First World War the franchise was extended in many countries, both to women and to previously ineligible men. In Britain, for example, the electorate had been similarly increased, with approximately 14 million new electors added to the electoral rolls. Predictions of destabilization ushered in by franchise extensions were ultimately unfulfilled (Ogg, 1918). Though the British Labour Party did increase its share of the vote from $6.4 \%$ to $23 \%$, its number of seats only went from 42 to 57 . As in the 1910 election, the Conservatives emerged as the largest party with its share of the vote declining from $47 \%$ to 39\% (Craig, 1976). The revolutionary nature of the election results in Ireland therefore stands in stark contrast to continuity in Britain, where franchise changes did not correspond to a pronounced political realignment, even with the same electoral system (Tanner, 2003 p.388). Whether changes in voting rights may have played a role in shaping the Sinn Féin victory 
remains, therefore, an open question. Studying the 1918 election in Ireland allows us to better understand the importance of the franchise changes that occurred during the interwar years - a period of dramatic political, economic and social change across the world.

\section{Data}

Addressing the question of whether the results of the 1918 election were associated with changes in the composition of the electorate required linking constituency-level election results to demographic and socio-economic information for these districts. The 1918 electoral map of Ireland consisted of 103 constituencies electing 105 MPs to Westminster. All were single-seat constituencies with the exception of Cork City and Dublin University, which each elected two members. ${ }^{12}$ To generate a socio-demographic profile of each electoral district, we linked individual level information from the 1911 Census of Ireland, available from the National Archives of Ireland, to constituency boundaries (see figure 1). ${ }^{13}$ Unfortunately constituency boundaries did not directly correspond to the administrative areas recorded in the census and, as such, the matching of information was required. Using parliamentary reports on electoral constituency boundaries we matched the 3,655 district electoral divisions of Ireland (DEDs) to 100 parliamentary electoral constituencies. ${ }^{14}$ Each individual in the 1911 census was first identified as residing in one of 3,655 District Electoral Divisions (DEDs) which we then aggregated to the 100 parliamentary constituencies in Ireland. To match DEDs to parliamentary constituencies that were redrawn in 1918 we used information on constituency boundaries as described in the Report of the Boundary Commission (1917). Where constituency boundaries were defined using the report of the Boundary Commission (Ireland) under the Redistribution

\footnotetext{
12 Election data was obtained from ARK Northern Ireland Elections database (accessed 4 March 2015)

${ }^{13}$ A digital map of 1918 constituency boundaries was kindly provided by Ian Gregory (Gregory et al., 2014)

14 There were four University seats in total: two from Dublin University and one each from the National University of Ireland and Queen's University Belfast. These seats are excluded from our analysis.
} 
of Seats Act (1885), we used the 1901 census summary reports to firstly link DEDs to Baronies (the next level of aggregation up from DEDs, c.330 baronies in Ireland) and then matched Baronies to 1918 electoral constituencies using Baronies and Electoral Constituencies (1885). ${ }^{15}$

Our principal variables of interest are those relating to newly enfranchised voters. The female share of the electorate variable, Share female electors, is defined as the share of female electors in the total electorate in each constituency, as described in UK parliamentary papers (UK Parliament, 1918). Unfortunately this source does not list the number of male electors in each constituency who are 'new' and 'old' but simply categorises by gender and type of franchise (e.g. local or parliamentary). To estimate the new male franchise for each constituency we use the difference between the male local government franchise and the male parliamentary franchise in 1918 as shown in equation 1.

\section{(1) New male electorate $=1918$ male parl.electorate -1918 male local electorate}

Put simply, we use the 1918 male local electorate as a proxy for the pre-1918 parliamentary electorate, and from this, infer the increase in male voters in each constituency. We consider this a suitable proxy for a number of reasons. Under the 1898 Local Government Act, the local government franchise was extended to include all male householders or occupiers (McManus, 2013). However the local government franchise was applied at the household level and therefore disenfranchised, among others, younger, single men who lived with their fathers. ${ }^{16}$ These men were also unable to vote in parliamentary elections before 1918, when a similar 'household’ qualification was employed. Indeed according to Tanner (2003 p.119) “there was considerable continuity between the pre-war parliamentary franchise and the post-war

\footnotetext{
15 The constituent DEDs of a parliamentary constituency were not listed in the 1885 volume. When a barony straddled a constituency boundary we endeavoured to include the barony in the constituency in which the majority of the barony was located.

${ }^{16}$ Most male householders had gained the vote before 1918 under the 1867 and 1884 Reform Acts. The proportion of adult males disenfranchised before 1918 varied across the UK however, ranging from one-third in England and Wales to one-half in Ireland (Cunningham, 2014).
} 
municipal franchise”. According to the Handbook of Local Government in Ireland, the local electorate was "all Parliamentary electors and of all peers and women who, but for their being peers or women, would be entitled to be Parliamentary electors” (Clancy, 1899 p.4). ${ }^{17}$ As a further robustness check on the use of male local electors in 1918 as a proxy for the previous male parliamentary electorate, we compare the figures for the male parliamentary electorate in 1910 to male local electorate in 1918 for the constituencies where boundaries remained the same between elections - comparing the 'true' old electorate with our local electorate proxy. Although this leaves us with only 57 constituencies that we can reasonably compare, the correlation between the male parliamentary electorate in 1910 and the male local electorate in 1918 is extremely high at 0.9 , providing reassurance regarding the use of this proxy measure. ${ }^{18}$ From the information on men entitled to vote in local elections we generate a variable, Share new males, which is our estimate of new male electors as a proportion of the total electorate. The inclusion of this variable can help us identify whether newly enfranchised male electors gave disproportionate support to Sinn Féin.

The census information allows us to consider the socio-economic characteristics of each constituency. ${ }^{19}$ We classify occupations by HISCO codes originally created by Fernihough, Ó Gráda, and Walsh (2015) which are then categorised as a HISCLASS codes (van Leeuwen and Maas, 2011). The HISCLASS coding scheme is then further matched to the occupational classifications used in Connor (2019). For example the variable Share Farmers is the proportion of the male voting-age population that listed their occupation as "farmer" in the 1911 Census. ${ }^{20}$ From the census information we also construct variables that capture religious

\footnotetext{
${ }^{17}$ The 1918 act did simplify the qualifications for local government electors but it was still fundamentally a household franchise.

${ }^{18}$ One important change to the franchise qualification brought in by the 1918 act was the reduction of the residency period from 12 months to six months.

${ }^{19}$ Of course the demographic profile of a constituency in 1911 may differ somewhat from that of 1918 . We will address this point in the robustness section.

${ }^{20} \mathrm{~A}$ full list of variables and definitions is presented in the appendix.
} 
composition, average age, household size, land values and the share of Irish Speakers. For the analysis of turnout in the election we also consider female literacy and participation rates.

The descriptive statistics (Table 1) reveal some of the differences in the demographic profiles of the constituencies. The proportion of new female electors varies considerably, from $30 \%$ to $44 \%$, while the proportion of new male electors varies between $3 \%$ and $34 \%$. With respect to socio-economic variables, the proportion of the voting-age male population who are farmers ranges from $0 \%$ to $71 \%$ while Skilled Workers ranges from 5\% to 53\%. Likewise the religious divisions are evident, with some constituencies being as high as 99\% Roman Catholic while others are as low as $7 \%$.

\section{Analysis}

Understanding Sinn Fein Support: Regression Analysis

As discussed above, contrasting explanations have been provided for the success of Sinn Féin in the 1918 General Election. Broadly categorized, we can separate the divergent theses explaining the electoral swing to militant republicanism in 1918 into several hypotheses. The first explanation - the franchise extension hypothesis - could be considered within the framework of traditional theories of non-random franchise extension. Under this hypothesis, the extension of voting rights to previously non-franchised groups permitted a more representative 'latent mandate' to emerge from the Irish people. This proposes that those groups enfranchised in 1918 were disproportionately likely to support Sinn Féin, with the existing literature, and indeed contemporaries, suggesting that new voters tended to be younger and poorer and that Sinn Féin support was greater among young people (Farrell, 1971; McConnel, 2004). If true, then we should expect to see greater support for Sinn Féin in areas with relatively larger numbers of enfranchised men and women. The alternative explanations imply that the electoral success of Sinn Féin was the result of a change in preferences on behalf of the 
electorate - that is the events of Easter 1916 and its aftermath, the conscription crisis, the perceived failure of the IPP to achieve Home Rule, or perhaps some other factor, led to a switch in voter allegiance within the Nationalist movement, from constitutional to republican. In the analysis that follows we will test these various hypotheses in an effort to better understand the determinants of the Sinn Féin victory in 1918.

As a first pass, looking at the simple correlation between the share of female electors and the Sinn Féin vote in contested constituencies as shown in figure 2 is informative. The graph shows a strong negative relationship between the share of women in the electorate and support for Sinn Féin, with a correlation coefficient of -0.59. Generally speaking, where women made up a greater proportion of the electorate, the Sinn Féin vote share was lower. Figure 3 shows the correlation between the share of new male electors and Sinn Féin vote shares. Here, the opposite relationship is apparent. A higher proportion of new male electors is positively associated with the Sinn Féin vote share, albeit with a weaker correlation coefficient of 0.32 .

Of course, these bivariate relationships, however revealing, cannot be interpreted as direct proof of differential voting as the observed relationship may be a product of confounding factors related to both the number of new electors and support for Sinn Féin. The multivariate regression results reported in table 2 address this issue. The extent to which franchise extension can explain the observed voting patterns of the Irish electorate sheds light on whether the 'latent mandate' or 'preference change' theories of 1918 carry more statistical weight. Equation (2) illustrates the testing framework:

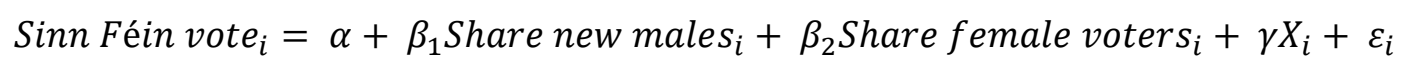

Where Sinn Féin vote is the vote share of Sinn Féin in constituency $i$. On the right-hand-side we include our variables of interest to test 'franchise extension' hypothesis while $X$ is a vector 
of control variables. ${ }^{21}$ Column 1 of table 2 examines the relationship between the share of new electors and support for Sinn Féin after including some baseline controls: turnout, average age, the mean and standard deviation of household size and the proportion of the constituency that are Catholic. ${ }^{22}$ In our analysis we restrict our sample to those constituencies actively contested by Sinn Féin. ${ }^{23}$ The results in column 1 are consistent with the relationships between the Sinn Féin vote share and new electors represented in figures 2 and 3 . There is a weak and statistically insignificant positive relationship between the Sinn Féin vote share and the share of new male electors. The relationship between female electors and Sinn Féin vote is negative although statistically insignificant. The implied magnitude is relatively large however a one standard deviation increase (0.03) in new female electors associated with a 2 percentage-point decrease in the Sinn Féin vote share.

We next turn to the relationship between support for Sinn Féin and economic characteristics at the constituency level to explore whether support for Sinn Féin varied according to the socioeconomic makeup of the constituency. Column 2 of table 2 includes variables capturing economic characteristics of constituencies, such as the occupational structure and the rateable value of land and building assets, as reported in the 1911 census. The baseline controls from regression 1 are maintained. While our proxy for wealth (rateable value) does not, all else equal, appear to be related to support for Sinn Féin, we do observe something of a class gradient, with white-collar and skilled occupations negatively associated with Sinn Féin support.

\footnotetext{
${ }^{21}$ We note that as Sinn Féin did not contest the prior General Election, the vote level mechanically equals the change in the vote. Similarly, the share of new electors variable is also a change relative to the last election. We can thus implicitly interpret these coefficients in a similar manner to a first-difference framework. This implicit interpretation does not extend to the analysis of parties that contested the previous elections.

22 These variables are considered as baseline controls due to the mechanical way in which they may be related to the franchise and support for Sinn Féin. For example, Sinn Féin's vote share may rise as turnout falls. The relationship between new electors and turnout is explored in table 5.

${ }^{23}$ In 25 constituencies Sinn Féin were unopposed while they did not contest another 5 constituencies due to an electoral pact with the IPP in Ulster (Laffan, 2005).
} 
Column 3 tests the hypothesis that support for Sinn Féin in 1918 was driven by the impact of 1916 and its aftermath on public opinion. Estimating public sentiment is clearly a difficult task and as such we must rely on proxy variables to test this hypothesis. The first variable we construct to understand 1916 sentiment is the number of 1916 prisoners deported from a constituency. In the immediate aftermath of the 1916 Rising, the British authorities imposed martial law and rounded up almost 2,500 individuals from across the country thought to have had some involvement in the rebellion and deported them to prisoner-of-war camps in Britain. Although many of the deportees had little direct involvement in the events of 1916, their arrest and deportation is thought to have alienated public opinion and contributed to the increase in support for the political inheritors of the 1916 Rising, namely Sinn Féin. We use the geocoded addresses of these deportees and place them within electoral constituency boundaries (Travers, 2017).

A second measure of sentiment is also included in the regression: donations made to the Irish National Aid Association and Volunteer’s Dependants Fund (INAAVDF) in 1916 and 1917. The Irish National Aid Association (INAA) was founded the month after the Easter Rising to solicit donations to support the veterans of 1916 and their dependents. Shortly after its creation, the INAA merged with the more militant Veterans’ Dependents' Fund (VDF) founded by Kathleen Clarke, whose husband Tom had been executed for his part in the Rising. Michael Collins, a veteran of 1916 and a member of the IRB, was appointed Secretary and used it as the financial basis for the renewal of the revolutionary movement and as such, the INAAVDF was firmly associated with the radical republican movement (Murphy, 2014). ${ }^{24}$ According to Nic Dháibhéid (2012) the INAAVDF “played a decisive role in shaping the popular memory

\footnotetext{
${ }^{24}$ We refer to the donations here simply as "INAA".
} 
of the Easter Rising as well as laying the foundations for a reinvigorated political and military campaign after 1917.”

The notionally benevolent nature of the INAA permitted them to publish lists of donors. We scanned and transcribed these donations and, where feasible, geolocated their source. After excluding donations from diasporic groups, we were left with approximately 17,000 observations of individual donations that we linked to individual constituencies. ${ }^{25}$ We then were able to aggregate the total value of donations made in each constituency.

The results presented in column 3 offer support to the hypothesis that the 1916 Rising and its aftermath radicalised public opinion and drove support for Sinn Féin. Both the number of post1916 deportees and the value of donations made to the INAA (both scaled by population) are positively associated with support for Sinn Féin. The legacy of the 1916 Rising appears important to understanding voting in the 1918 election.

Column 4 in table 2 considerers the additional hypothesis that the events of 1918 itself were crucial to the Sinn Féin victory. The Conscription crisis and the imprisonment of prominent Sinn Féin figures following the supposed discovery of a 'German Plot' between Sinn Féin and the German Empire to stage an insurrection in Ireland is thought to have shifted public opinion in favour of Sinn Féin. Indeed the IPP complained that without the arrests, in so far as they positioned Sinn Féin as the most stalwart opponent of conscription, they would have decisively beaten Sinn Féin in the East Cavan by-election in June 1918 (Laffan, 2005). To test the hypothesis that the events of 1918 were associated with support for Sinn Féin we consider two variables in column 4. The first variable is the share of Military Voters in a constituency. In 1918 voters still on active service were entitled to an absentee ballot in the constituency in which they would have otherwise been entitled to vote. The number of Military voters in each

\footnotetext{
${ }^{25}$ Addresses relating to donations outside of Ireland were excluded from the analysis.
} 
constituency is recorded in the UK parliamentary papers. In terms of a proxy for attitudes towards conscription, we assume that this be interpreted as a rough measure of support for the war and correspondingly, a more favourable inclination towards conscription. As such we might expect that military voters would be negatively related to support for Sinn Féin.

We also include in column 4 a dummy variable to capture whether or not the Sinn Féin candidate was in prison at the time of the election to examine whether this gave any electoral benefit to Sinn Féin. The results indicate that, all else equal, support for Sinn Féin was lower where military voters constituted a great share of the electorate, lending support to the hypothesis that the conscription crisis may have played a role in determining the results of the election of 1918, while the imprisonment of a Sinn Féin candidate did not appear to bring any electoral benefit, all else equal.

The relationship between long-run factors and support for Sinn Féin is tested in column 5 of table 2. The regression includes a measure of the impact of the Irish Famine that occurred in the mid- $19^{\text {th }}$ century. Specifically our measure of famine distress is the change in population between 1841 and 1851 (Fernihough and Ó Gráda, 2018). As can be seen from the descriptive statistics in table 1 , the famine was a demographic catastrophe, with the average decline of population experienced being $18 \%$ while some areas experienced a decline of $45 \%$ over the period. That the British authorities failed to save Ireland from the famine was a recurring theme among many Irish nationalists, including Sinn Féin (Laffan, 2005). Indeed a recent paper by Narciso and Severgnini (2017) explicitly makes the link between famine experience and the probability of engaging in rebellious activities. Likewise, the impact of the famine may have had a bearing on support for Sinn Féin in 1918.

Also included are variables intended to capture cultural nationalism. In the late $19^{\text {th }}$ century, Irish culture witnessed a popular revival, with the Irish language and traditional Irish games and cultural activities seeing a sustained recovery following centuries of decline. At the 
forefront of this movement was the Gaelic League, a society founded in 1893 to promote traditional Irish culture. Although not politically aligned to either nationalist party, radical republicans and Sinn Féin leaders featured among the ranks of the League. To assess the relationship between the emergence of cultural nationalism and support for Sinn Féin we include the number of Gaelic League branches as well the share of the population that speaks the Irish language alongside our measure of famine distress. The coefficients in column 5 of table 2 suggest that where the impact of the famine was demographically most severe, Sinn Féin support was higher. In contrast, there is little evidence that Gaelic League branches or Irish speakers were associated with higher Sinn Féin vote shares, all else equal. ${ }^{26}$ The fact that the famine experience is associated with greater support for Sinn Féin suggests long-run factors mattered for Sinn Féin support and is consistent with the intergenerational transmission of radicalisation suggested in Narciso and Severgnini (2017).

The final column in table 2 presents a regression in which all variables are considered jointly. Although collinearity is likely present, the results are largely consistent with the specifications that tested the various hypotheses in turn. ${ }^{27}$ Changes in the franchise do not appear to have benefitted Sinn Féin. In fact the enfranchisement of women may have worked against the party in 1918.

\section{The Irish Parliamentary Party and Unionists}

Having tested the various hypothesis related to support for Sinn Féin, we also consider the vote shares of the IPP (Table 3) and Unionist (Table 4) parties as outcomes of interest. ${ }^{28}$ Many of

\footnotetext{
${ }^{26}$ Although perhaps surprising given the overlapping memberships between the Gaelic League and radical republican organisations, the Gaelic League was non-political and non-sectarian, with Protestants prominent among its leadership. It should also be noted that we control for religion in the regressions and that dropping this variable changes the sign of the Gaelic League coefficient.

${ }^{27}$ The issue of collinearity and variable selection is considered in the robustness section.

${ }^{28}$ In the robustness section we consider the vote shares of each party (and non-voting) as a system using a Seemingly Unrelated Regression model.
} 
these results complement those for Sinn Féin. Where more new voters were present the IPP had a higher vote share, all else equal, although this is not statistically significant. Furthermore the IPP had a higher vote share where the impact of the famine was less pronounced, mirroring the result found for Sinn Féin. Finally the results in table 5 reveal that where more new male electors were present the Unionists vote share was lower. Taken together with those for Sinn Féin, these results suggest that the franchise did play a role in the outcome of the 1918 election, although not quite that suggested in the literature. Women electors were associated with lower support for Sinn Féin while new male electors were associated with lower support for Unionists.

\section{Understanding Turnout}

The final section of the electorate not yet considered is those that did not vote in the 1918 election at all: non-voters. What constituency-level characteristics and conditions were associated with non-voting? Table 5 considers a number of factors that may have been associated with turnout in the election. Firstly, we examine the relationship between non-voting (or equivalently, voter turnout) and the new electors. If voting is a habit, then the relative inexperience of the Irish electorate in 1918 may be related to turnout. Column 1 of table 5 considers non-voters as a share of the electorate as the dependent variable with the measure of new male and female franchise as explanatory variables. The positive and significant coefficient on Share Female Electors indicates that where there were more female electors, non-voting was higher (or equivalently turnout was lower). Indeed a one standard deviation increase in the share of female electors is associated with a three percentage point increase in non-voting, a sizeable effect. In contrast, the coefficient corresponding to new male electors is small and not statistically significant. 
Following from the results in model 1, we explore the relationship between the new electorate and non-voting further by including measures of women's labour market participation and literacy. We also control for overall constituency wealth, as captured by valuation per acre. We find a strong and statistically significant negative relationship between these variables and nonvoting. Where female labour force participation and literacy are higher, non-voting is lower. This again is suggestive of a link between female electors and overall turnout.

Column 3 considers the impact of the pre-war women's suffrage movement on turnout in 1918. Based on Ward (2017), we geocoded the locations of suffrage society branches and their events and activities in 1913. From this we constructed variables that capture the number of branches and the number of pro-women's suffrage activities recorded in 1913 in each constituency, scaled by area. Our results suggest that non-voting was lower in areas that saw greater pre-war suffrage activity, again highlighting a link between women electors and turnout.

Finally column 4 considers environmental factors that may have influenced turnout in 1918, namely terrain (as measured by ruggedness), transport connectivity (as measured by the number of train stations) and rainfall in December 1918. A final variable that we construct is intended to capture a unique aspect of the election: that it took place during the 'Spanish Flu' pandemic of 1918. As the outbreak of influenza led to the cancellation of number of public meeting (including political rallies), as well as high rates of mortality and illness, it may have played a part in determining turnout in 1918. As such we measure the impact of the 1918 influenza outbreak by death rates recorded by the Registrar-General (Registrar General, 1919). Figure 4 shows the geographic variation in death rates from influenza (and pneumonia) in 1918. The regressions in column 4 suggest that while rainfall, the number of train stations and terrain ruggedness were not related to turnout, the influenza pandemic may have indeed reduced turnout in 1918. 
The regression results in table 2 tell a consistent story. The estimated coefficients do not support the hypothesis that Sinn Féin's dramatic electoral success was driven by newly enfranchised voters. If anything, female enfranchisement went against Sinn Féin. We find evidence that the differences in constituencies’ propensity to vote Sinn Féin was underpinned by economic and social factors. Using the Z-score transformation allows us to directly compare the effect size of each explanatory variable individually. However, the individual and collective explanatory power of these variables is still not completely captured by this framework.

Table 6 addresses this shortcoming by providing a measure of both the relative influence of each individual regressor and also groups of regressors, where our groups match the four broad explanatory categories. The first column in table 6 displays the coefficient estimates alongside clustered standard errors associated with Sinn Féin support across the 70 contested constituencies. These results are identical to those listed in the last column of table 2 . The $R^{2}$ value indicates that approximately 92\% of the Sinn Féin vote is accounted for by the model’s explanatory variables. The second column of table 6 decomposes the $R^{2}$ statistic using the $I m g$ method proposed by Groemping (2006). This method, originally conceived by Lindeman et al. (1980), yields relative $R^{2}$ contributions by averaging across all orderings of the explanatory variables or, as in column 3, groups of explanatory variables. This approach is superior to more ad-hoc approaches such as partial- $R^{2}$ statistic comparisons because it calculates relative importance measures that are invariant to regressor multicollinearity.

Our collection of baseline control variables appear, unsurprisingly, to account for most of the model's explanatory power. Column 3 indicates that $37 \%$ of the explained variation is accounted for by these factors. ${ }^{29}$ Column 2 reveals that the Catholic variable is the most

\footnotetext{
${ }^{29}$ The column totals in both columns (2) and (3) add to 100 so the numbers here indicate what share of the $92 \%$ of the model variation is accounted for by the various explanatory variables.
} 
influential, accounting for one-third of the total explained variation. ${ }^{30}$ The second single largest contributor to the model's explanatory power in the variable measuring INAA donations. By this metric the 1916 rising can be seen as an important element underling Sinn Féin’s success. Broadly speaking, economic circumstances appear to matter and contribute to around 20 per cent of the explained variation. Comparing across the occupational distribution, Sinn Féin support dwindled as the share of those in skilled occupations rose. Also noteworthy is relevance of population change related to the Great Famine. Constituencies that were worse hit, in terms of population loss, were more likely to lend support to the Sinn Féin cause at the ballot box. Finally, these results, as before, indicate that franchise effects were important. As tempting as it is to assume that a dramatic change in the electorate caused an equally dramatic change in the composition of Ireland's parliamentary representatives our results on this front suggest the reverse. Newly enfranchised female electors can account for approximately $8 \%$ of the explained variation. Under the counterfactual of "no female enfranchisement," our model predicts that Sinn Féin’s vote share may have actually increased.

\section{Robustness}

\section{Demographic Change}

A criticism that may be levelled at our linking of census data to election results is that our electoral data is from 1918 while our demographic and economic data comes from the 1911 census. Although this is the closest census year available, our picture of the electorate of a constituency may not be accurate if demographics shifted significantly in the seven years between 1911 and 1918. Indeed there are obvious factors that may have influenced the demographics of a constituency over the period, such as the impact of wartime recruitment,

\footnotetext{
${ }^{30}$ Columns (2) and (3) are comparable but not equal. The reason for this is that column (2) extracts the relative importance of each regressor by averaging across all model permutations wherein each explanatory variable enters as a singleton. Column (3) applies the same procedure but assesses influence on the basis that the variables are groups and enter and exit model partitions in blocks.
} 
disruption of migration patterns or simply changes resulting from long-run demographic forces. However we do have some demographic information for 1918: the size of the male and female electorates. We can use this to test the accuracy of demographic data by estimating the number of male and female electors using the census data from 1911 and comparing it to the actual number of electors in each constituency in 1918. Specifically, we estimate the male electorate by counting the number of men over 20 years of age and the number of women over 30 in each constituency. Of course this is a relatively rough estimate of the male and female electorates; many otherwise eligible male electors would have been disqualified due to various registration restrictions such as a minimum residency requirement. Likewise, not all women over 30 would have been entitled to vote as this was restricted to rate payers or the wives of male rate payers. Nonetheless the exercise represents a useful test of the accuracy of our data. Figures 5 and 6 show the correlations between the actual electorate in 1918 and our estimate based on the 1911 census.

Clearly there is a very strong correlation between our estimates based on the 1911 census and the actual electorates in 1918. For men the correlation is 0.85 and for women, 0.83 . These close relationships, despite the various reasons that these figures may legitimately diverge, reassures us that our matching exercise is valid and that any demographic shifts between 1911 and 1918 are not likely to invalidate our results.

\section{Variable Selection}

As we have seen, the results presented earlier are somewhat sensitive to the exact specification of the regression equation. This is inevitable when restricted to aggregated data with 70 observations and potentially correlated variables. To determine the robustness of the results, there is an argument for excluding some variables on statistical grounds. While we argue our themed regression analysis that tests each hypothesis in turn provides a logically coherent way 
to interpret the data, we include a battery of robustness checks using several recently developed machine learning algorithms.

Tables A1 to A4 in the Appendix explore the determinants of voting patterns using four separate statistical objective functions. ${ }^{31}$ Column 1 is the baseline OLS specification, included for comparison. Although OLS minimizes prediction error conditional on unbiased point estimates, this commitment to unbiasedness may come at a cost of large variance. An alternative approach permits a more flexible specification where bias in the point estimates is permitted if it reduces variance "enough", as defined by some statistical measure like the AIC or BIC. With this approach in mind, column 2 presents Ridge regression results, a technique that minimizes prediction error while maintaining the same set of variables. The ridge point estimates are in general biased. If the point estimates do not deviate much from the OLS results, it is instructive that the OLS results provide good predictive power as well being unbiased.

Columns 3 through 5 of Tables A1 to A4 perform lasso estimation. Like ridge regression, the lasso minimizes a statistic (e.g. residual sum of squares) but also has the advantage of producing sparse solutions i.e. variable selection. We provide three variants implemented by the Ahrens et al. (2018) LASSOPACK program. Overall these robustness checks support the main findings of our baseline analysis. With respect to Sinn Féin support, the ridge regression provides point estimates very similar to the OLS results. The lasso variable selection methods differ in their analysis, but overall they suggest that, consistent with our earlier results, female

\footnotetext{
${ }^{31}$ Most machine learning algorithms do not have well-defined clustered standard errors, so we report point estimates alone.
} 
electors (negatively), INAA donations (positively), and Famine-era population change (negatively) are associated with support for Sinn Féin.

\section{Constituencies where Sinn Féin was Unopposed}

As highlighted earlier, Sinn Féin faced no electoral competition for 25 seats in Ireland in 1918 and their candidate was therefore deemed elected automatically. Although we exclude these constituencies from our analysis and only consider electoral contests, it is possible to analyse what characteristics increased the odds that a constituency was uncontested, in particular whether the same factors that are associated with the Sinn Féin vote share are also related to whether opposing parties decided not to run against Sinn Fein. Table A5 presents results of a logistic regression where a dummy variable indicating when Sinn Féin was unopposed as the dependent variable. The table suggests that, although certain characteristics increased the odds of a constituency being contested, such as the share of Catholics (not reported), contested and non-contested districts were not statistically different across many aspects. However it does appear experiencing a greater population decline between 1841 and 1851 increased the odds that Sinn Féin was unopposed.

\section{Seemingly Unrelated Regression}

In our previous analysis we examined the vote shares of Sinn Féin and other parties independently when in practice vote shares of different parties are jointly determined. Seemingly Unrelated Regression (SUR) models offer an alternative econometric approach. The advantage of the SUR approach is that it models the election outcomes in a multivariate framework, which is particularly of interest to scholars analysing multiparty elections (Jackson, 
2002). Thus, we model the respective vote shares for Sinn Féin, the IPP, and Unionists (all unionist parties) alongside the share of non-voters in following system of equations:

$$
\begin{gathered}
\text { SFVote }=\alpha_{S F}+\boldsymbol{X} \boldsymbol{\beta}_{S F}+\varepsilon_{S F} \\
\text { IPPVote }=\alpha_{I P P}+\boldsymbol{X} \boldsymbol{\beta}_{I P P}+\varepsilon_{I P P} \\
\text { UNVote }=\alpha_{U N}+\boldsymbol{X} \boldsymbol{\beta}_{U N}+\varepsilon_{U N}
\end{gathered}
$$

where the number of explanatory variables in the matrix $\boldsymbol{X}$ changes according to the model specification and the error terms $\varepsilon$ correlate. As in Wooldridge (pp. 167-8, 2004) we indirectly estimate the intercept and slope coefficients of the non-voting equation via the following restrictions:

$$
\begin{gathered}
\alpha_{N V}=1-\alpha_{S F}-\alpha_{I P P}-\alpha_{U N} \\
\boldsymbol{\beta}_{\boldsymbol{N V}}=-\boldsymbol{\beta}_{\boldsymbol{S F}}-\boldsymbol{\beta}_{I P P}-\boldsymbol{\beta}_{U N}
\end{gathered}
$$

which ensures that vote shares in each constituency, by definition, sum to one. These coefficient restrictions and the correlation of the error terms means that variables that increases the vote share for one party must decrease the vote share for others in equal measure. ${ }^{32}$

The results of the SUR estimation can be seen in tables A6 to A11 of the appendix. Again our conclusions based on the individual regression analyses are basically unchanged. Support for Sinn Féin is negatively associated with new female voters while INAA donations and the severity of population decline over the period of the Irish famine are positively associated with the Sinn Féin vote share. Where there are more women electors, turnout is also lower. Taken together, these reinforce our view that the franchise extension was not responsible for the Sinn

\footnotetext{
${ }^{32}$ To ensure concordance with our previous model results we calculated the standard errors using a cluster bootstrap.
} 
Féin victory in 1918 and that understanding the change in public opinion in the aftermath of the 1916 Rising is crucial to understanding Sinn Féin’s electoral success.

\section{Discussion}

The finding that franchise extension to women in 1918 may have in fact have worked against Sinn Féin should perhaps not be surprising. Evidence from other countries during the interwar period suggests that women voters were anti-extremist and more conservative (Boak, 1989; Turner, 1987). The radicalism of Sinn Féin's position therefore may have had relatively less appeal to women. Indeed that the vote was restricted to women over 30 may have reinforced this. The assertion that the Sinn Féin victory was, in the words of an often referenced contemporary observer, 'a triumph of the young over the old' is not reflected in the age of the 1918 electorate (Ferriter, 2018). Although the new male voters were younger than average than the old electorate, the new female voters were older, leaving the average age of the electorate almost unchanged. ${ }^{33}$ The 1918 reforms not only disenfranchised by age but also by class due to the property requirement that was applied. In fact it is estimated that as many as 2 million working-class women over 30 (or over $20 \%$ of the population over 30 ) were disenfranchised by these provisions across the UK (Muggeridge, 2018). Finally new electors may not have voted in large numbers in 1918, a finding consistent with the fact that the UK 1918 election turnout rate (57\%) was lower than any election since (UK Parliament, 2016). ${ }^{34}$ Indeed our analysis suggests a relatively strong link between the share of women voters in a constituency and turnout in Ireland. ${ }^{35}$ Taken together the results suggest that newly-enfranchised male voters

\footnotetext{
${ }^{33}$ Using the census information we estimated the average age of male household-heads over 21 (old electorate) at 51. The average of non-household head males (new male voters) was 36 while the average age of women over thirty was 51. Overall the average age for the 1918 electorate was 47.

${ }^{34}$ Turnout in Ireland was 66\% in contested constituencies. It should also be noted that uncontested seats were not unique to Ireland in 1918. 107 out of 707 seats were uncontested across the UK (Audickas et al., 2017).

35 In a supplementary analysis we included enfranchisement-turnout interactions as additional explanatory variables. The effect of new male enfranchisement was not conditional upon turnout (i.e. there was no statistical association found across the board). It appears that new female electors support was conditional upon turnout. In constituencies where turnout was higher the new female electors were even less likely to vote for Sinn Féin
} 
did not give disproportionate support to Sinn Féin, while new women voters were associated with a lower Sinn Féin vote.

What can explain support for Sinn Féin in 1918? We test alternative hypothesis and find evidence that public opinion was radicalised by the 1916 Rising. We also show that Sinn Féin won a greater share of the vote where the impact of the Great Irish Famine was most keenly felt. In addition we explore the nature of turnout in 1918 and find that where more women voters were present, turnout was lower. We also find however that areas with higher female literacy, female labour force participation rates and more pre-war women’s suffrage activities had higher rates of turnout, all else equal.

\section{Conclusion}

On the eve of the 1918 election, the IPP MP for West Mayo, William Doris, wrote to the party leader, John Dillon, speculating how new voters would cast their votes:

"On the old register we were perfectly safe and the question is how the extended franchise will affect us. I am satisfied that a majority of the women over thirty will be with us, but the vast majority of the boys from 21 to 30 will be against us. They appear to have gone mad and no doubt we will have all kinds of intimidation, personation, etc.” (Doris, 1918, cited in McConnel, 2004 p.375)

The comment about female electors may well have been accurate and is broadly consistent with our findings, although our result don't support the claim that new male electors would favour Sinn Féin. However the claim that the IPP under the old register would have been safe is less convincing. Indeed Doris himself polled 2,363 fewer votes than 1910, even under a

compared to their counterparts in other constituencies. However, this interaction effect disappears in the fully specified model. These results are available upon request. 
vastly enlarged electorate. Clearly, absolute support for the IPP had declined in the face of Sinn Féin's triumph.

A little more than a month after the election, the Sinn Féin deputies followed through on the policy of abstentionism put forward in their election manifesto and convened the first meeting of an independent Irish Parliament, Dáil Éireann, on 21 January $1919 .{ }^{36}$ With the ratification that day of the 1916 proclamation of independence and the adoption of a new constitution, Ireland began the journey to formal independence and ultimately the establishment of the 26county Irish Republic. The members of the First Dáil firmly believed that their convincing victory in 1918 had given them a mandate to sever political ties with Britain (Coleman, 2013). It is of course impossible to know what issues motivated individual voters in 1918. Nonetheless the election was ultimately framed as a clear-cut choice about the future direction of Irish nationalism. As the Meath Chronicle (21 December 1918, p.1) put it:

“...the ballot boxes will reveal whether the people of Ireland support the historic claim that our nation should enjoy her rights as an unfettered and independent Republic or whether Ireland is content to return to the wilderness of Parliamentarian opportunism.”

That the election was more akin to a referendum on the future direction of Irish Nationalism is perhaps most evident in the returns for the two-seat constituency of Cork City, where each voter was given two votes to distribute to any of the six candidates (two Sinn Féin, two IPP and two Unionists). In the end, $94 \%$ of voters chose two candidates from the same party (Coakley, 1994 p.43). ${ }^{37}$ It is clear that the events between 1916 and 1918 led an increasing number of people to abandon support for the IPP and back the more radical form of nationalism

\footnotetext{
${ }^{36}$ In fact less than one third of the 103 Irish MPs returned in 1918 attended. The Unionists, although invited, did not attend. Many other Sinn Féin MPs were unable to attend, it was noted, as they were declared 'faoi ghlas ag Gallaibh' - imprisoned by the foreigner (Farrell, 1994 p.2).

${ }^{37}$ Sinn Féin took both seats with $68 \%$ of the votes cast.
} 
offered by Sinn Féin. Although it is difficult to say with certainty how and why people voted in 1918, the results of this paper suggest that, even without a change in the franchise, the election of 1918 would still have marked a turning point in Irish history. In short, the Sinn Féin victory in 1918 can be seen as a change of heart among the Irish electorate, not a change in composition. More generally, it demonstrates that dramatic electoral outcomes do not require dramatic changes in political participation.

\section{References}

Ahrens, A., Hansen, C.B., \& Schaffer, M.E. (2019). lassopack: Model selection and prediction with regularized regression in Stata. arxiv:1901.05397.

Aidt, T. S. and B. Dallal (2008). Female voting power: the contribution of women's suffrage to the growth of social spending in Western Europe (1869-1960). Public Choice 134 (3), 391417.

Aidt, T. S., M. Daunton, and J. Dutta (2010). The retrenchment hypothesis and the extension of the franchise in England and Wales. The Economic Journal 120 (547), 990-1020.

Aidt, T. S. and P. S. Jensen (2013). Democratization and the size of government: evidence from the long 19th century. Public Choice 157 (3), 511-542.

Aidt, T. S., and Mooney, G. (2014). Voting suffrage and the political budget cycle: Evidence from the London Metropolitan Boroughs 1902-1937. Journal of Public Economics, 112, 5371.

Audickas, L., Hawkins, O. and Cracknell, R. (2017). UK Election Statistics: 1918-2017. House of Commons briefing paper, CBP7529. 
Berlinski, S. and T. Dewan (2011), "The Political Consequences of Franchise Extension: Evidence from the Second Reform Act", Quarterly Journal of Political Science Vol. 6: No. 34, 329-376.

Blackburn, R. (2011), Laying the Foundations of the Modern Voting System: The Representation of the People Act 1918. Parliamentary History, 30 33-52.

Boak, H. L. (1989). Our last hope; women's votes for Hitler: A reappraisal. German Studies Review 12 (2), 289-310.

Caramani, D. (2004). The Nationalization of Politics: The Formation of National Electorates and Party Systems in Western Europe. Cambridge Studies in Comparative Politics. Cambridge University Press.

Clancy, J.J. (1899). A Handbook of Local Government in Ireland, Sealy, Bryers and Walker, Dublin.

Coakley, J. (1994). The election that made the first Dáil. In B. Farrell (Ed.), The Creation of the Dáil, Chapter 3, pp. 31-44. Dublin: Blackwater Press.

Coleman, M. (2013). The Irish Revolution, 1916-1923. Seminar Studies in History. Taylor \& Francis.

Collins, L. (2016). 1916: The Rising Handbook. O'Brien Press.

Corder, J. K., and Wolbrecht, C. (2006). Political Context and the Turnout of New Women Voters after Suffrage. Journal of Politics, 68 (1), 34-49.

Craig, F. (1976). British Electoral Facts 1885-1975. Palgrave Macmillan UK.

Cunningham, H. (2014). The Challenge of Democracy: Britain 1832-1918. New History of Britain. Taylor \& Francis. 
de Bromhead, A. (2018). Women voters and trade protectionism in the interwar years. Oxford Economic Papers 70 (1), 22-46.

Doris, W. (1918). Letter to John Dillon, 13 December. TCD, DP, MS 6753/362.

Evans, G. (1999). The End of Class Politics? Class Voting in Comparative Context. Oxford scholarship online. Oxford University Press.

Farrell, B. (1971). The founding of Dáil Éireann: parliament and nation building, Volume 2. Gill and Macmillan.

Ferriter, D. (2018). Sinn Féin and the Conscription Crisis, The Irish Times, 24 April.

Fernihough, A. and Ó'Gráda, C. (2018). Population and Poverty in Ireland on the Eve of the Great Famine. Available at SSRN 3296291.

Fernihough, A., Ó'Gráda, C. and Walsh, B.M. (2015). Intermarriage in a divided society: Ireland a century ago, Explorations in Economic History, vol. 56, 1-14.

Fitzpatrick, D. (1978). The geography of Irish nationalism 1910-1921. Past \& Present (78), 113-144.

Fujiwara, T. (2015). Voting technology, political responsiveness, and infant health: Evidence from Brazil. Econometrica, 83(2), 423-464.

Garvin, T. (1981). The Evolution of Irish Nationalist Politics. Holmes \& Meier.

Gerould, K. F. (1925). Some American Women and the Vote. Scribner's Magazine 127 (May), 449-52.

Gregory, I, Cunningham, N, Lloyd, C, Shuttleworth, I \& Ell, P (2014). Troubled geographies: a spatial history of religion and society in Ireland. Spatial Humanities, Indiana University Press, Bloomington, Ind. 
Groemping, U. (2006) Relative Importance for Linear Regression in R: The Package relaimpo, Journal of Statistical Software17, Issue 1. Downloadable at http://www.jstatsoft.org/v17/i01

Henry, R.M. (1920). The Evolution of Sinn Fein. NY Huebsch, London.

Honohan, Patrick, and Brendan Walsh (2002). "Catching up with the leaders: the Irish hare." Brookings Papers on Economic Activity 2002.1 (2002): 1-57.

Jackson, J.E. (2002). “A Seemingly Unrelated Regression Model for Analyzing Multiparty Elections.” Political Analysis, vol. 10, no. 1, 49-65.

Johnson, S. (19917). Johnson's Atlas \& Gazetteer of the Railways of Ireland, Leicester, UK: Midland.

Laffan, M. (2005). The Resurrection of Ireland: The Sinn Féin Party, 1916-1923. Cambridge University Press.

Lee, J. J. (1989). Ireland, 1912-1985: Politics and Society. Cambridge University Press.

Lehmann-Hasemeyer, S., Hauber, P., and Opitz, A. (2014). The Political Stock Market in the German Kaiserreich — Do Markets Punish the Extension of the Suffrage to the Benefit of the Working Class? Evidence from Saxony. The Journal of Economic History, 74(4), 1140-1167 Lindeman, R.H., Merenda, P.F. and Gold, R.Z. (1980) Introduction to Bivariate and Multivariate Analysis, Glenview IL: Scott, Foresman.

Lindert, P. (2004). Growing Public: Volume 1, The Story: Social Spending and Economic Growth Since the Eighteenth Century. Growing Public. Cambridge University Press.

Lott, Jr, J. R. and L. W. Kenny (1999). Did women's suffrage change the size and scope of government? Journal of Political Economy 107 (6), 1163-1198. 
McConnel, J. (2004). The franchise factor in the defeat of the Irish Parliamentary Party, 18851918. The Historical Journal 47 (2), 355-377.

McManus, M. (2013). The Republic of Ireland in Chandler, J.A. (ed.), Local Government in Liberal Democracies: An Introductory Survey. Routledge, 28-52.

Merriam, C. E., and H. F. Gosnell (1924). Non-voting: Causes and Methods of Control. University of Chicago Press.

Mill, H.R. and M. de Carle S. Salter (1919) British Rainfall, 1918 available from UK Met Office, https://digital.nmla.metoffice.gov.uk/ accessed Sept 2018.

Miller, D. (1973). Church, State, and Nation in Ireland, 1898-1921. University of Pittsburgh Press.

Miller, G. (2008). Women's suffrage, political responsiveness, and child survival in American history. The Quarterly Journal of Economics, 123 (3), 1287-1327.

Muggeridge, A., (2018). The Missing Two Million: The Exclusion of Working-class Women from the 1918 Representation of the People Act. Revue Française de Civilisation Britannique. French Journal of British Studies, 23(XXIII-1).

Murphy, W. (2017). Imprisonment, 1915-1918 in J. Crowley, D. O Drisceoil, and M. Murphy (eds) Atlas of the Irish Revolution, NYU Press, 319-322.

Murphy, W. (2014). Political Imprisonment and the Irish, 1912-1921, Oxford University Press. Neary, P. (1984). The Failure of Economic Nationalism. The Crane Bag, 8 (1), 68-77. Nic Dháibhéid, C. (2012). The Irish National Aid Association and the radicalization of public opinion in Ireland, 1916-1918, The Historical Journal, 55, 705-729 
Niemi, R. G., H. W. Stanley, and C. L. Evans (1984). Age and Turnout Among the Newly Enfranchised: Life Cycle versus Experience Effects. European Journal of Political Research 12 (December): 371-386.

Ogg, F. A. (1918). The British Representation of the People Act. The American Political Science Review 12 (3), 498-503.

Polanyi, K. (1944). The great transformation: The political and economic origin of our time. Beacon Press.

Registrar-General for Ireland (1919). Annual Report of the Registrar-General for Ireland, HMSO available at https://www.nisra.gov.uk/sites/nisra.gov.uk/files/publications/1918.pdf (accessed October 2018).

Sinn Féin (1918). General election manifesto to the Irish people - an mórthoghadh feisirí gairmscoile do mhuintir na heireann. Sinn Féin.

Tanner, D. (2003). Political Change and the Labour Party 1900-1918. Cambridge University Press.

Townshend, C. (2013). The Republic: The Fight for Irish Independence, 1918-1923. Penguin Books Limited.

Travers, P. (2017). The Conscription Crisis and the General Election of 1918 in J. Crowley, D. O Drisceoil, and M. Murphy (eds) Atlas of the Irish Revolution, NYU Press, 323-329.

Turner, J. (1987). The labour vote and the franchise after 1918: an investigation of the English evidence. In P. Denley and D. Hopkin (Eds.), History and Computing, Chapter 23, p. 136-146. Manchester University Press. 
UK Parliament (1918). Parliamentary and Local Government Electors (United Kingdom). Return to an Address of the Honourable the House of Commons, (138) xix, 925, 16 October. House of Commons accounts and papers. Proquest LLC.

UK Parliament (2016). General election turnout. www.parliament.uk. Accessed Jan 2018.

van Leeuwen, M. and I. Maas (2011). Hisclass: A Historical International Social Class Scheme. G - Reference Information and Interdisciplinary Subjects Series. Leuven University Press.

United Irish League, \& Irish Parliamentary Party (1918). Irish Party manifesto: Appeal to the people. Dublin: United Irish League.

Ward, A. J. (1974). Lloyd George and the 1918 Irish conscription crisis. The Historical Journal 17 (1), 107-129.

Ward, M. (2017). Feminism and Nationalism: women and political activism in J. Crowley, D. O Drisceoil, and M. Murphy (eds) Atlas of the Irish Revolution, NYU Press, 134-137.

Wheatley, M. (2005). Nationalism and the Irish Party: Provincial Ireland 1910-1916. OUP Oxford.

Wilson, M.F.J., O'Connell, B., Brown, C., Guinan, J.C., Grehan, A.J. (2007). Multiscale terrain analysis of multibeam bathymetry data for habitat mapping on the continental slope. Marine Geodesy 30: 3-35).

Wooldridge, J.M. (2004). Econometric Analysis of Cross Section and Panel Data. Boston, MA: Massachusetts Institute of Technology.

Voucharas, G. and D. Xefteris (2018) Women's Political Power and Environmental Outcomes, University of Cyprus Working Papers in Economics 07-2018, University of Cyprus Department of Economics. 


\section{Tables and Figures}

TABLE 1: DESCRIPTIVE STATISTICS

\begin{tabular}{lccccc}
\hline Statistic & $\mathrm{N}$ & Mean & St. Dev. & Min & Max \\
\hline Sinn Féin vote & 100 & 0.494 & 0.336 & 0.000 & 1.000 \\
IPP vote & 100 & 0.117 & 0.134 & 0 & 1 \\
Unionist vote & 100 & 0.154 & 0.231 & 0.000 & 0.752 \\
Non-vote & 100 & 0.229 & 0.156 & 0.000 & 0.722 \\
Share female electors & 100 & 0.361 & 0.029 & 0.295 & 0.437 \\
Share new males & 100 & 0.237 & 0.049 & 0.031 & 0.344 \\
Share Farmers & 100 & 0.344 & 0.225 & 0.002 & 0.713 \\
Share Ag. Labourer & 100 & 0.127 & 0.074 & 0.006 & 0.342 \\
Share Urb. Labourer & 100 & 0.132 & 0.065 & 0.035 & 0.294 \\
Share White Collar & 100 & 0.103 & 0.069 & 0.033 & 0.428 \\
Share Skilled & 100 & 0.195 & 0.127 & 0.047 & 0.527 \\
Share None/Other & 100 & 0.099 & 0.039 & 0.050 & 0.245 \\
Catholic & 100 & 0.721 & 0.278 & 0.072 & 0.989 \\
Turnout & 100 & 0.771 & 0.156 & 0.278 & 1.000 \\
SF unopposed & 100 & 0.250 & 0.435 & 0 & 1 \\
SF no contest & 100 & 0.050 & 0.219 & 0 & 1 \\
Population density (log) & 100 & 4.382 & 2.258 & 2.364 & 10.159
\end{tabular}




\begin{tabular}{lccccc} 
Average age & 100 & 44.175 & 2.509 & 39.231 & 47.778 \\
Value per acre & 100 & 20.189 & 57.461 & 0.100 & 395.268 \\
Pop change 1841-51 & 100 & -18.194 & 17.731 & -44.488 & 32.212 \\
Gaelic League branches & 100 & 1.520 & 1.636 & 0 & 9 \\
SF Candidate in prison & 100 & 0.350 & 0.479 & 0 & 1 \\
Military voters & 100 & 0.057 & 0.038 & 0.009 & 0.154 \\
INAA Donations pc & 100 & 0.012 & 0.011 & 0.000 & 0.054 \\
1916 Deportees pc & 100 & 0.001 & 0.002 & 0 & 0 \\
Share Irish speakers & 100 & 0.162 & 0.225 & 0.012 & 0.825 \\
Suffrage societies per km 100 & 0.003 & 0.026 & 0.000 & 0.257 \\
Suffrage activity per km & 100 & 0.002 & 0.012 & 0.000 & 0.116 \\
Female literacy rate & 100 & 0.814 & 0.079 & 0.513 & 0.952 \\
Female participation rate & 100 & 0.222 & 0.030 & 0.153 & 0.295 \\
Flu rate & 100 & 3.598 & 1.522 & 1.067 & 6.385 \\
Ruggedness & 100 & 9.412 & 7.899 & 0.375 & 45.750 \\
Train stations & 100 & 10.450 & 8.502 & 0 & 42 \\
Rainfall Dec 1918 & 100 & 139.563 & 39.429 & 83.820 & 307.848 \\
\hline
\end{tabular}

TABLE 2: UNDERSTANDING THE SINN FÉIN VOTE

\begin{tabular}{|c|c|c|c|c|c|c|}
\hline & \multicolumn{6}{|c|}{ Dependent variable: } \\
\hline & \multicolumn{6}{|c|}{ SF Share } \\
\hline & $\begin{array}{c}\text { Franchise } \\
\text { (1) }\end{array}$ & $\begin{array}{c}\text { Economic } \\
\text { (2) }\end{array}$ & $\begin{array}{c}1916 \text { Opinion } \\
\text { (3) }\end{array}$ & $\begin{array}{c}1918 \text { Opinion } \\
\text { (4) }\end{array}$ & $\begin{array}{l}\text { Long Run } \\
\text { (5) }\end{array}$ & $\begin{array}{l}\text { All } \\
\text { (6) }\end{array}$ \\
\hline Share new males & $\begin{array}{c}0.001 \\
(0.007)\end{array}$ & & & & & $\begin{array}{c}0.005 \\
(0.010)\end{array}$ \\
\hline Share female electors & $\begin{array}{l}-0.020 \\
(0.012)\end{array}$ & & & & & $\begin{array}{c}-0.027^{* *} \\
(0.012)\end{array}$ \\
\hline Share Ag. Labourer & & $\begin{array}{l}-0.021 \\
(0.019)\end{array}$ & & & & $\begin{array}{l}-0.010 \\
(0.024)\end{array}$ \\
\hline Share Urb. Labourer & & $\begin{array}{c}0.003 \\
(0.016)\end{array}$ & & & & $\begin{array}{c}0.012 \\
(0.019)\end{array}$ \\
\hline Share White Collar & & $\begin{array}{c}-0.037^{* *} \\
(0.015)\end{array}$ & & & & $\begin{array}{l}-0.018 \\
(0.020)\end{array}$ \\
\hline Share Skilled & & $\begin{array}{c}-0.105^{* *} \\
(0.043)\end{array}$ & & & & $\begin{array}{l}-0.044 \\
(0.043)\end{array}$ \\
\hline Share None/Other & & $\begin{array}{c}0.017 \\
(0.012)\end{array}$ & & & & $\begin{array}{c}0.021^{*} \\
(0.012)\end{array}$ \\
\hline Value per acre (log) & & $\begin{array}{c}0.015 \\
(0.025)\end{array}$ & & & & $\begin{array}{c}0.051 \\
(0.032)\end{array}$ \\
\hline 1916 Deportees pc & & & $\begin{array}{l}0.015^{* *} \\
(0.006)\end{array}$ & & & $\begin{array}{l}0.014^{*} \\
(0.007)\end{array}$ \\
\hline
\end{tabular}


INAA Donations pc

SF Candidate in prison $\begin{array}{cc}0.003 & -0.002 \\ (0.011) & (0.009)\end{array}$

Military voters

Pop change 1841-51

Gaelic League branches

Share Irish speakers

\begin{tabular}{lcccccc}
\hline Baseline Controls & Yes & Yes & Yes & Yes & Yes & Yes \\
Observations & 70 & 70 & 70 & 70 & 70 & 70 \\
$\mathrm{R}^{2}$ & 0.856 & 0.873 & 0.866 & 0.855 & 0.882 & 0.920 \\
\hline
\end{tabular}

OLS regressions weighted by electorate. All explanatory variables are standardised using the Z-score transformation. Cluster robust standard errors in parentheses. All regressions include a constant. Baseline Controls: Share Catholic, Turnout, Average Age, mean and standard deviation of Household Size. ${ }^{* * *} \mathrm{p}<0.01$, ${ }^{* *} \mathrm{p}<0.05,{ }^{*} \mathrm{p}<0.1$

TABLE 3: UNDERSTANDING THE IPP VOTE

\begin{tabular}{|c|c|c|c|c|c|c|}
\hline & \multicolumn{6}{|c|}{ Dependent variable: } \\
\hline & \multicolumn{6}{|c|}{ IPP Share } \\
\hline & $\begin{array}{c}\text { Franchise } \\
\text { (1) }\end{array}$ & $\begin{array}{c}\text { Economic } \\
\text { (2) }\end{array}$ & $\begin{array}{c}1916 \text { Opinion } \\
\text { (3) }\end{array}$ & $\begin{array}{c}1918 \text { Opinion } \\
\text { (4) }\end{array}$ & $\begin{array}{l}\text { Long Run } \\
\text { (5) }\end{array}$ & $\begin{array}{l}\text { All } \\
(6)\end{array}$ \\
\hline Share new males & $\begin{array}{c}0.014 \\
(0.010)\end{array}$ & & & & & $\begin{array}{c}0.004 \\
(0.012)\end{array}$ \\
\hline Share female electors & $\begin{array}{c}0.017 \\
(0.014)\end{array}$ & & & & & $\begin{array}{c}0.008 \\
(0.014)\end{array}$ \\
\hline Share Ag. Labourer & & $\begin{array}{c}0.001 \\
(0.023)\end{array}$ & & & & $\begin{array}{l}-0.011 \\
(0.021)\end{array}$ \\
\hline Share Urb. Labourer & & $\begin{array}{c}0.021 \\
(0.027)\end{array}$ & & & & $\begin{array}{c}0.031 \\
(0.024)\end{array}$ \\
\hline Share White Collar & & $\begin{array}{c}0.022 \\
(0.029)\end{array}$ & & & & $\begin{array}{c}0.018 \\
(0.033)\end{array}$ \\
\hline Share Skilled & & $\begin{array}{l}0.067 \\
(0.056)\end{array}$ & & & & $\begin{array}{c}0.050 \\
(0.049)\end{array}$ \\
\hline Share None/Other & & $\begin{array}{c}0.008 \\
(0.025)\end{array}$ & & & & $\begin{array}{c}0.003 \\
(0.030)\end{array}$ \\
\hline Value per acre (log) & & $\begin{array}{c}-0.039 \\
(0.041)\end{array}$ & & & & $\begin{array}{c}-0.079^{* *} \\
(0.036)\end{array}$ \\
\hline 1916 Deportees pc & & & $\begin{array}{l}0.0004 \\
(0.014)\end{array}$ & & & $\begin{array}{c}0.007 \\
(0.015)\end{array}$ \\
\hline
\end{tabular}


INAA Donations pc

SF Candidate in prison

Military voters

$\begin{array}{cc}-0.0004 & 0.003 \\ (0.012) & (0.010)\end{array}$

Pop change 1841-51

(0.020)

Gaelic League branches

Share Irish speakers

\begin{tabular}{lcccccc}
\hline Baseline Controls & Yes & Yes & Yes & Yes & Yes & Yes \\
Observations & 70 & 70 & 70 & 70 & 70 & 70 \\
$\mathrm{R}^{2}$ & 0.580 & 0.597 & 0.573 & 0.570 & 0.632 & 0.682
\end{tabular}

OLS regressions weighted by electorate. All explanatory variables are standardised using the Z-score transformation. Cluster robust standard errors in parentheses. All regressions include a constant. Baseline Controls: Share Catholic, Turnout, Average Age, mean and standard deviation of Household Size. ${ }^{* * *} \mathrm{p}<0.01$, ${ }^{* *} \mathrm{p}<0.05,{ }^{*} \mathrm{p}<0.1$

TABLE 4: UNDERSTANDING THE UNIONIST VOTE

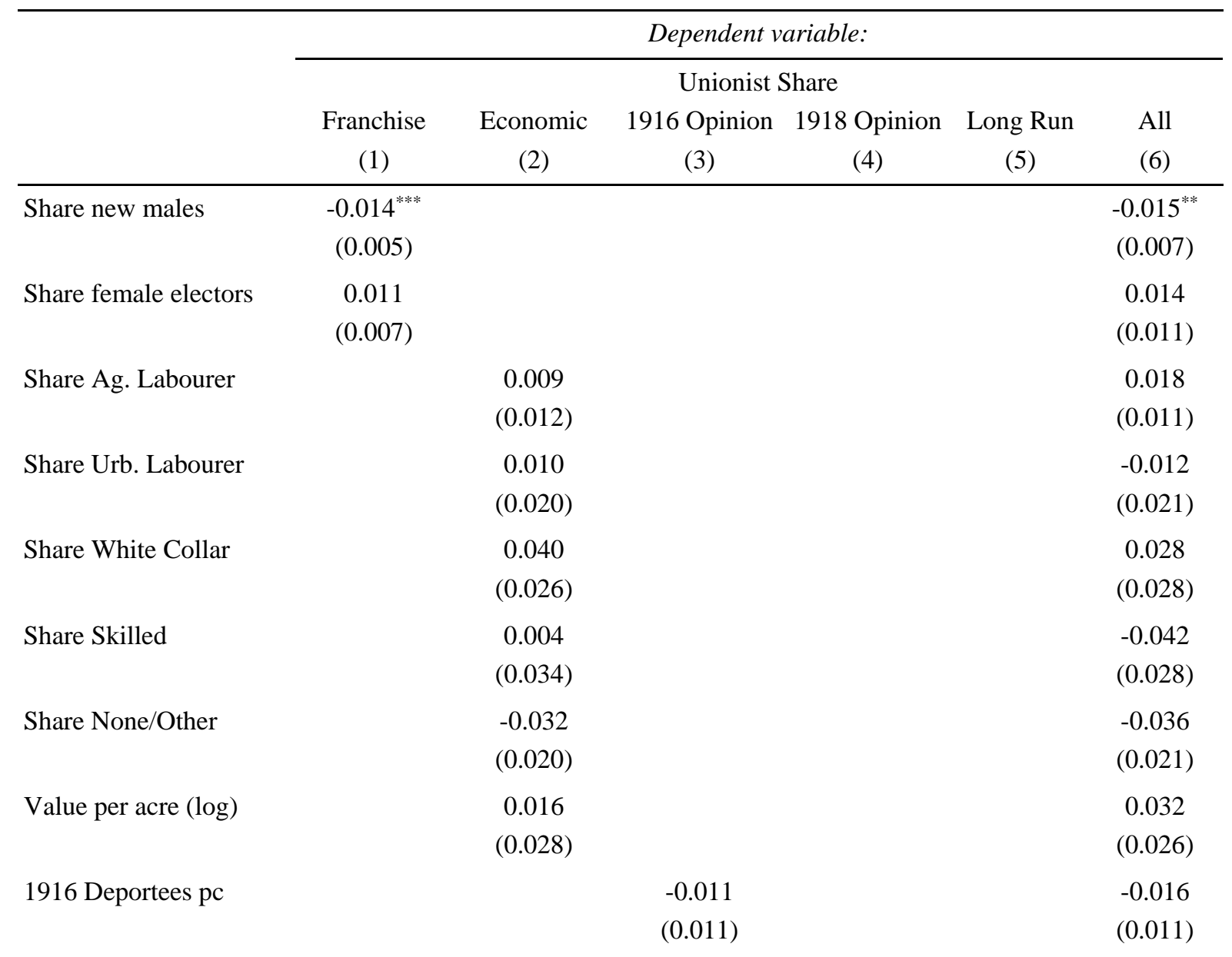


INAA Donations pc

SF Candidate in prison

Military voters

$$
-0.0003
$$

(0.008)

Pop change 1841-51

Gaelic League branches

Share Irish speakers

(0.011) (0.011)

\begin{tabular}{lcccccc}
\hline Baseline Controls & Yes & Yes & Yes & Yes & Yes & Yes \\
Observations & 70 & 70 & 70 & 70 & 70 & 70 \\
$\mathrm{R}^{2}$ & 0.953 & 0.953 & 0.950 & 0.949 & 0.954 & 0.972
\end{tabular}

OLS regressions weighted by electorate. All explanatory variables are standardised using the Z-score transformation. Cluster robust standard errors in parentheses. All regressions include a constant. Baseline Controls: Share Catholic, Turnout, Average Age, mean and standard deviation of Household Size. ${ }^{* * *} \mathrm{p}<0.01$, ${ }^{* *} \mathrm{p}<0.05,{ }^{*} \mathrm{p}<0.1$

TABLE 5: UNDERSTANDING TURNOUT

\begin{tabular}{|c|c|c|c|c|c|}
\hline & \multicolumn{5}{|c|}{ Dependent variable: } \\
\hline & $\begin{array}{c}\text { Franchise } \\
\text { (1) }\end{array}$ & $\begin{array}{c}\text { Economic } \\
\text { (2) }\end{array}$ & $\begin{array}{c}\text { Non-Voting } \\
\text { Suffrage Movement } \\
\text { (3) }\end{array}$ & $\begin{array}{c}\text { Environment } \\
\text { (4) }\end{array}$ & $\begin{array}{l}\text { All } \\
(5)\end{array}$ \\
\hline Share new males & $\begin{array}{c}0.001 \\
(0.007)\end{array}$ & & & & $\begin{array}{l}-0.007 \\
(0.008)\end{array}$ \\
\hline Share female electors & $\begin{array}{l}0.032^{* *} \\
(0.015)\end{array}$ & & & & $\begin{array}{l}0.036^{* *} \\
(0.014)\end{array}$ \\
\hline Female literacy rate & & $\begin{array}{c}-0.043^{* * *} \\
(0.015)\end{array}$ & & & $\begin{array}{c}-0.034^{* * *} \\
(0.012)\end{array}$ \\
\hline Female participation rate & & $\begin{array}{c}-0.027^{* * *} \\
(0.010)\end{array}$ & & & $\begin{array}{c}-0.029^{* * *} \\
(0.009)\end{array}$ \\
\hline Value per acre (log) & & $\begin{array}{c}0.001 \\
(0.018)\end{array}$ & & & $\begin{array}{l}-0.021 \\
(0.027)\end{array}$ \\
\hline Suffrage societies per km & & & $\begin{array}{c}0.005 \\
(0.005)\end{array}$ & & $\begin{array}{l}-0.004 \\
(0.003)\end{array}$ \\
\hline Suffrage activity per km & & & $\begin{array}{l}-0.008^{* *} \\
(0.004)\end{array}$ & & $\begin{array}{c}-0.019^{* * *} \\
(0.005)\end{array}$ \\
\hline Flu rate & & & & $\begin{array}{l}0.034^{*} \\
(0.019)\end{array}$ & $\begin{array}{c}0.026 \\
(0.019)\end{array}$ \\
\hline Ruggedness & & & & $\begin{array}{l}-0.018 \\
(0.011)\end{array}$ & $\begin{array}{l}-0.011 \\
(0.009)\end{array}$ \\
\hline
\end{tabular}


Train stations

\begin{tabular}{lcccc} 
& & 0.002 & 0.004 \\
& & $(0.013)$ & $(0.014)$ \\
& & 0.004 & 0.009 \\
& & & $(0.011)$ & $(0.012)$ \\
\hline Yes & Yes & Yes & Yes & Yes \\
75 & 75 & 75 & 75 & 75 \\
.172 & 0.227 & 0.120 & 0.162 & 0.337 \\
\hline
\end{tabular}

Rainfall Dec 1918

Baseline Controls

Observations

OLS regressions weighted by electorate. All explanatory variables are standardised using the Z-score transformation. Cluster robust standard errors in parentheses. All regressions include a constant. Baseline Controls: Share Catholic, Turnout, Average Age, mean and standard deviation of Household Size. ${ }^{* * *} \mathrm{p}<0.01$, ${ }^{* *} \mathrm{p}<0.05,{ }^{*} \mathrm{p}<0.1$

TABLE 6: DECOMPOSITION OF SINN FEIN VOTE R-SQUARED BY HYPOTHESES

OLS Ind. Contribution (\%) Group Contribution (\%)

(1)

(2)

(3)

\begin{tabular}{lccc}
\hline Share new males & $0.008(0.008)$ & 2.158 & 10.304 \\
Share female voters & $-0.027^{* *}(0.012)$ & 7.722 & \\
Share Ag. Labourer & $-0.016(0.020)$ & 1.740 & 19.534 \\
Share Urb. Labourer & $0.011(0.019)$ & 2.521 & \\
Share White Collar & $-0.020(0.022)$ & 1.620 & \\
Share Skilled & $-0.050(0.043)$ & 8.034 & \\
Share None/Other & $0.022^{*}(0.012)$ & 2.269 & \\
Value per acre (log) & $0.045(0.030)$ & 3.445 & \\
1916 Deportees & $0.012(0.007)$ & 2.461 & \\
INAA Donations pc & $0.019(0.014)$ & 12.318 & \\
SF Candidate in prison & $-0.003(0.008)$ & 1.426 & \\
Military voters & $-0.014(0.031)$ & 4.979 & \\
Pop change 1841-51 & $-0.050^{* *}(0.019)$ & 9.109 & \\
Gaelic League branches & $-0.026^{* *}(0.011)$ & 1.836 & \\
Share Irish speakers & $-0.014(0.017)$ & 1.402 & \\
Catholic & $0.111^{* * *}(0.019)$ & 32.966 & \\
Turnout & $0.016(0.010)$ & 0.570 &
\end{tabular}




$\begin{array}{lcc}\text { Mean Household size } & 0.006(0.014) & 0.323 \\ \text { SD Household size } & -0.005(0.004) & 0.380 \\ \text { Average age } & -0.009(0.029) & 2.720 \\ \text { Constant } & 0.349^{* * *}(0.007) & \end{array}$

Observations 70

$\mathrm{R}^{2} \quad 0.918$

Table depicts individual variables' contribution to the overall $\mathrm{R}^{2}$ from the "Understanding Sinn Féin Vote" analysis. Column 1 replicates that analysis. Columns 2 and 3 present the individual variables' and group hypotheses' share of the $\mathrm{R}^{2}$ statistic from Column 1.

${ }^{* * *} \mathrm{p}<0.01,{ }^{* *} \mathrm{p}<0.05,{ }^{*} \mathrm{p}<0.1$

Figure 1: Electoral Constituencies and Sinn Féin Vote Shares, 1918 


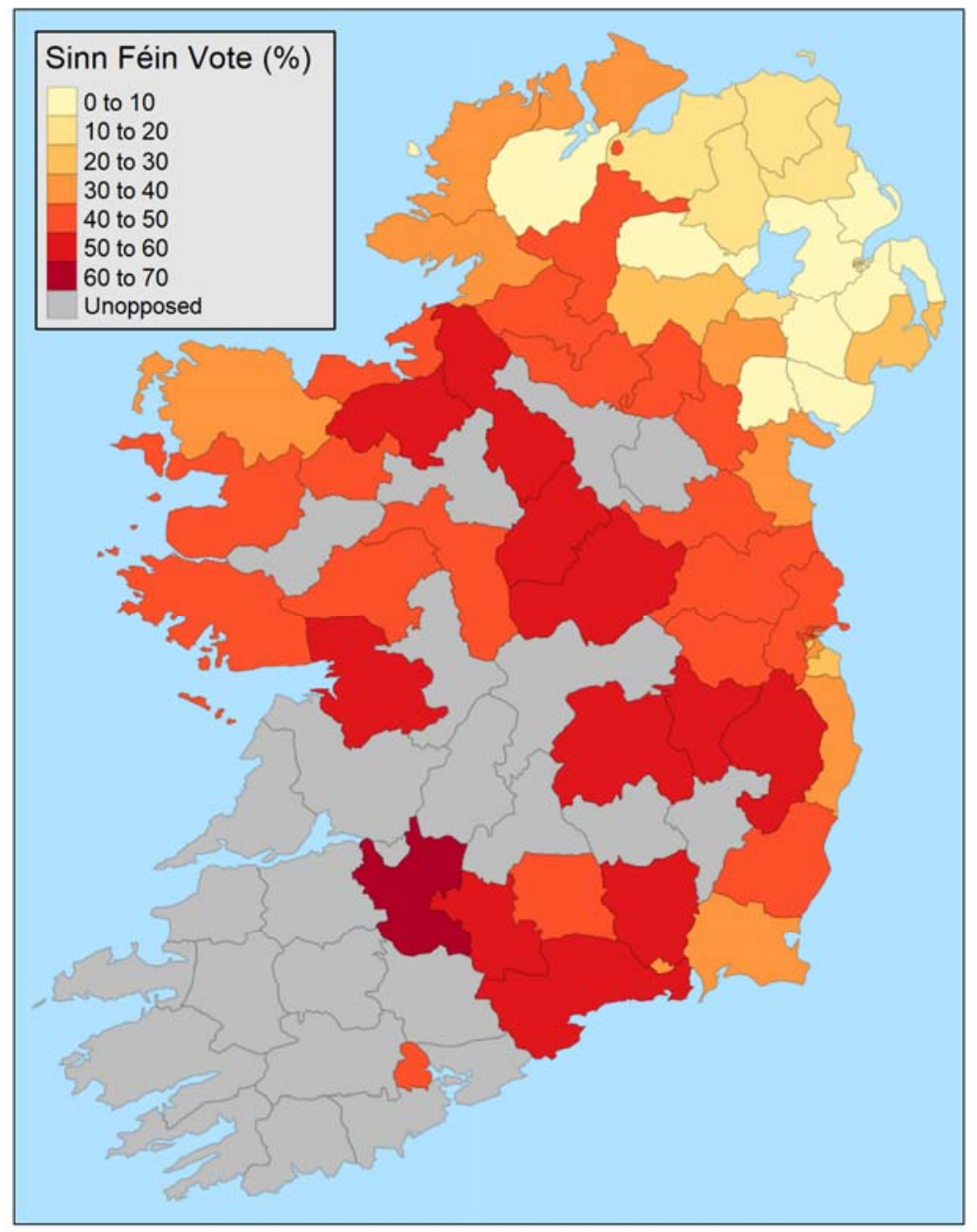

Figure 2: Share Female Electorate and Sinn Féin Vote Shares 


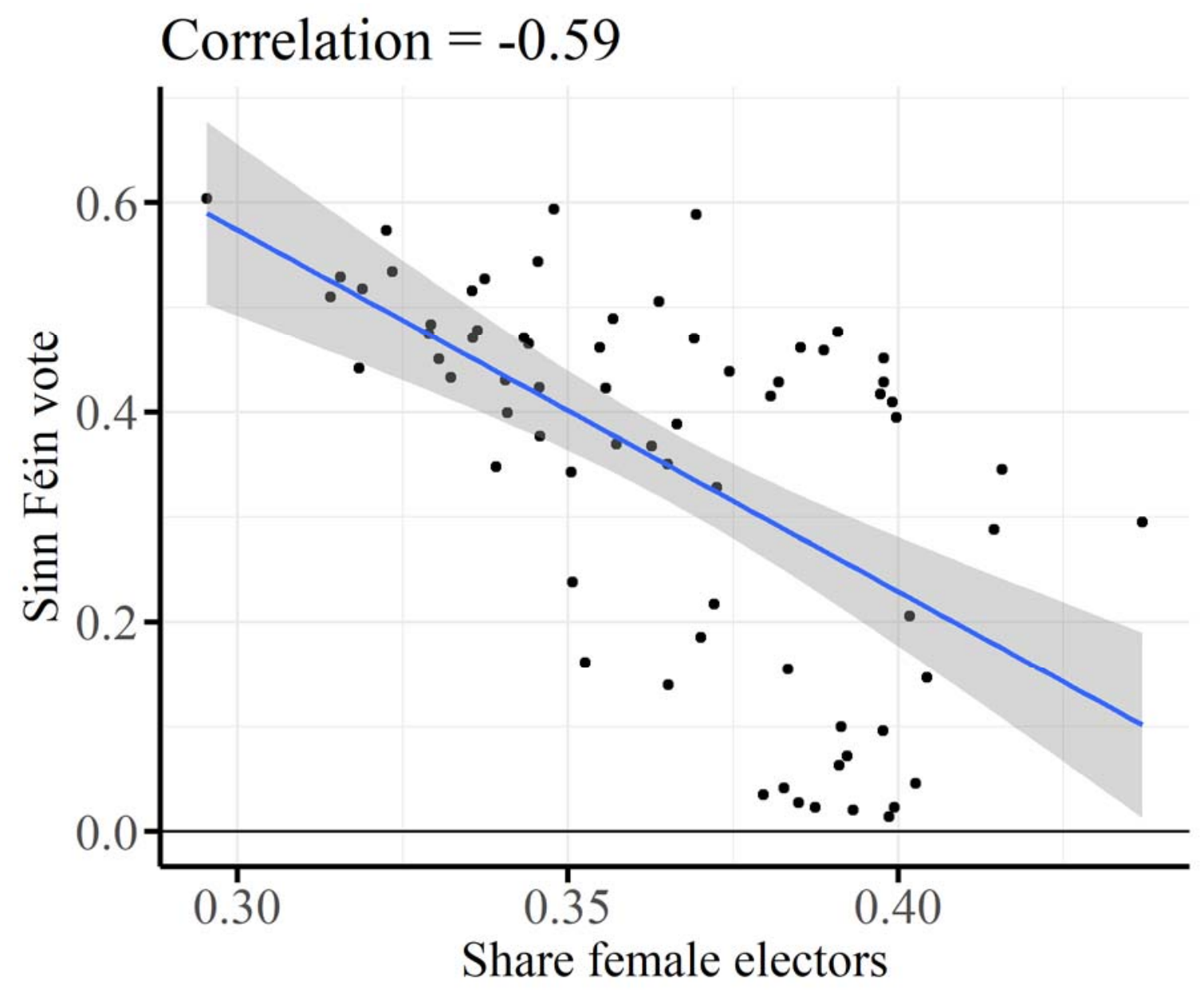

Figure 3: Share of newly enfranchised men and SF vote share in contested elections 


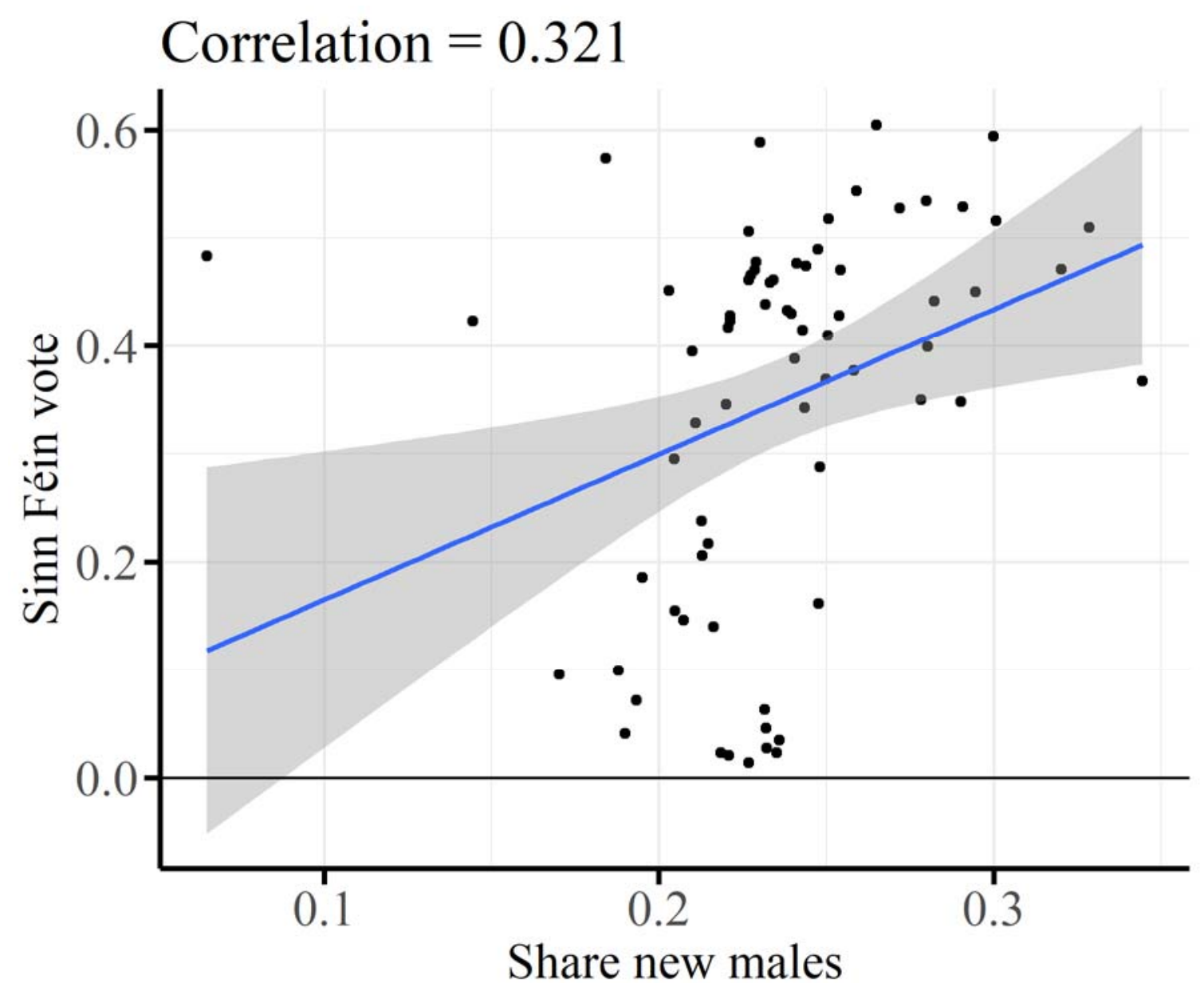


Figure 4: Death Rates from Influenza per 1,000 population in 1918

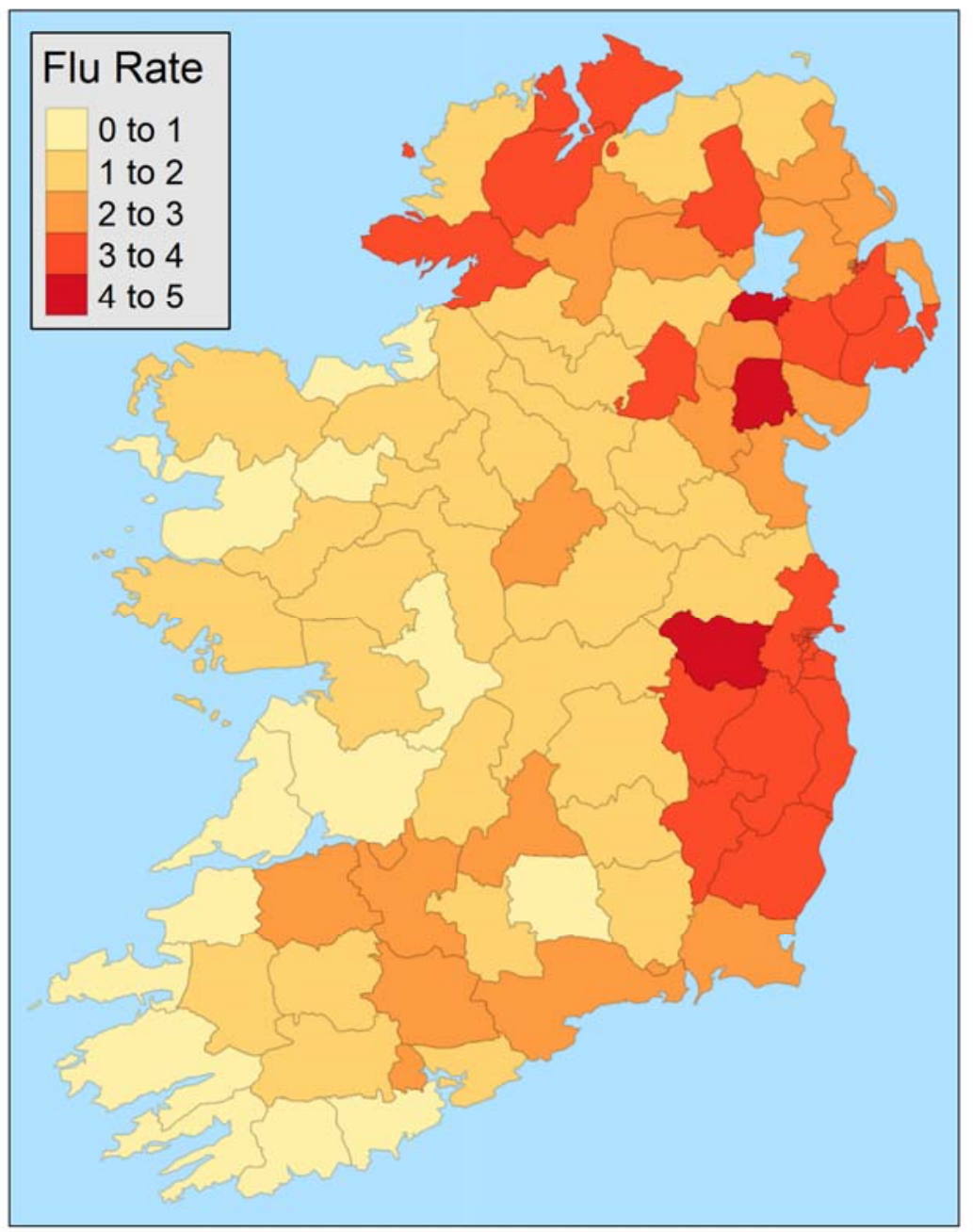


Figure 5: Actual versus predicted male electorate

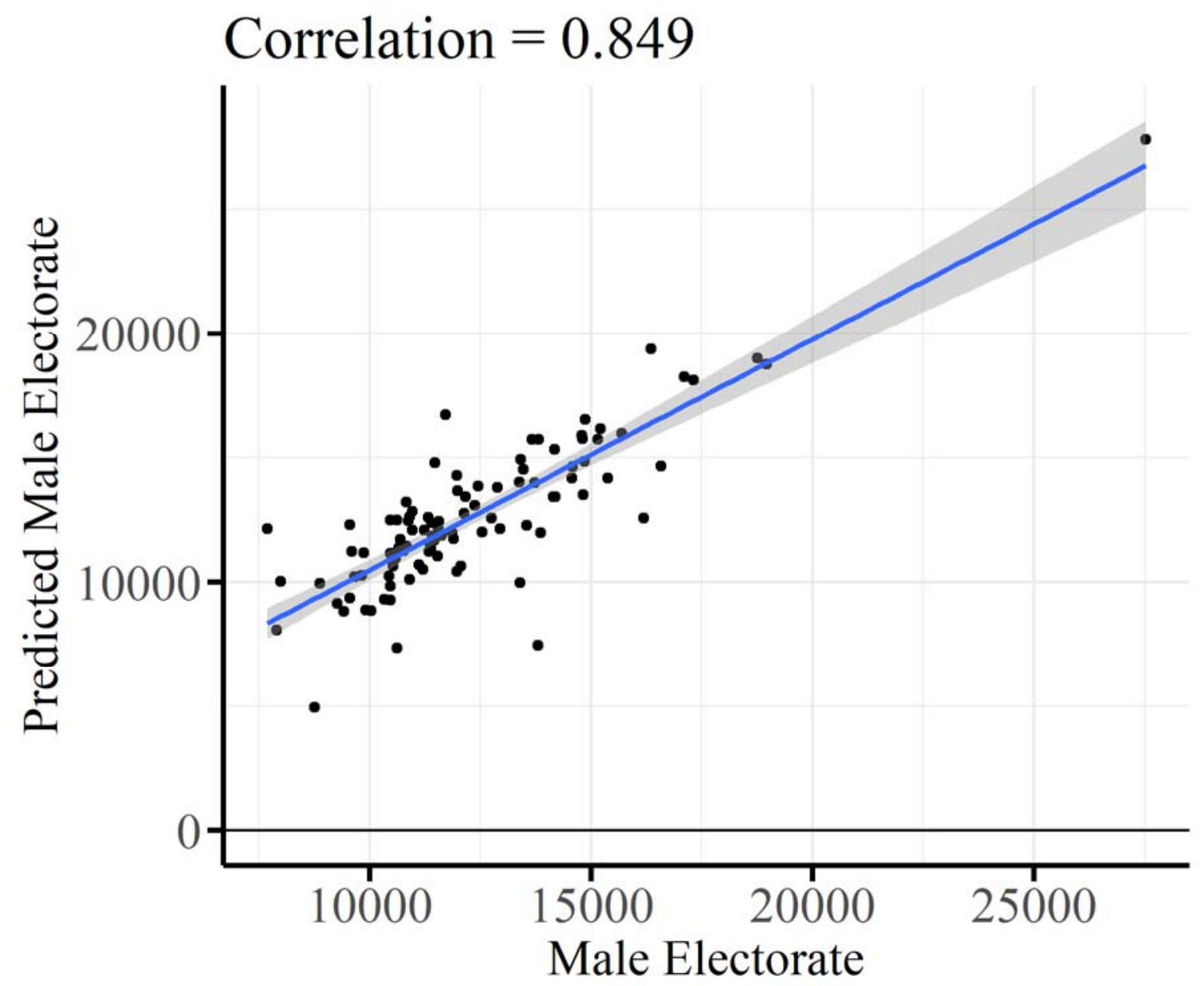


Figure 6: Actual versus predicted female electorate

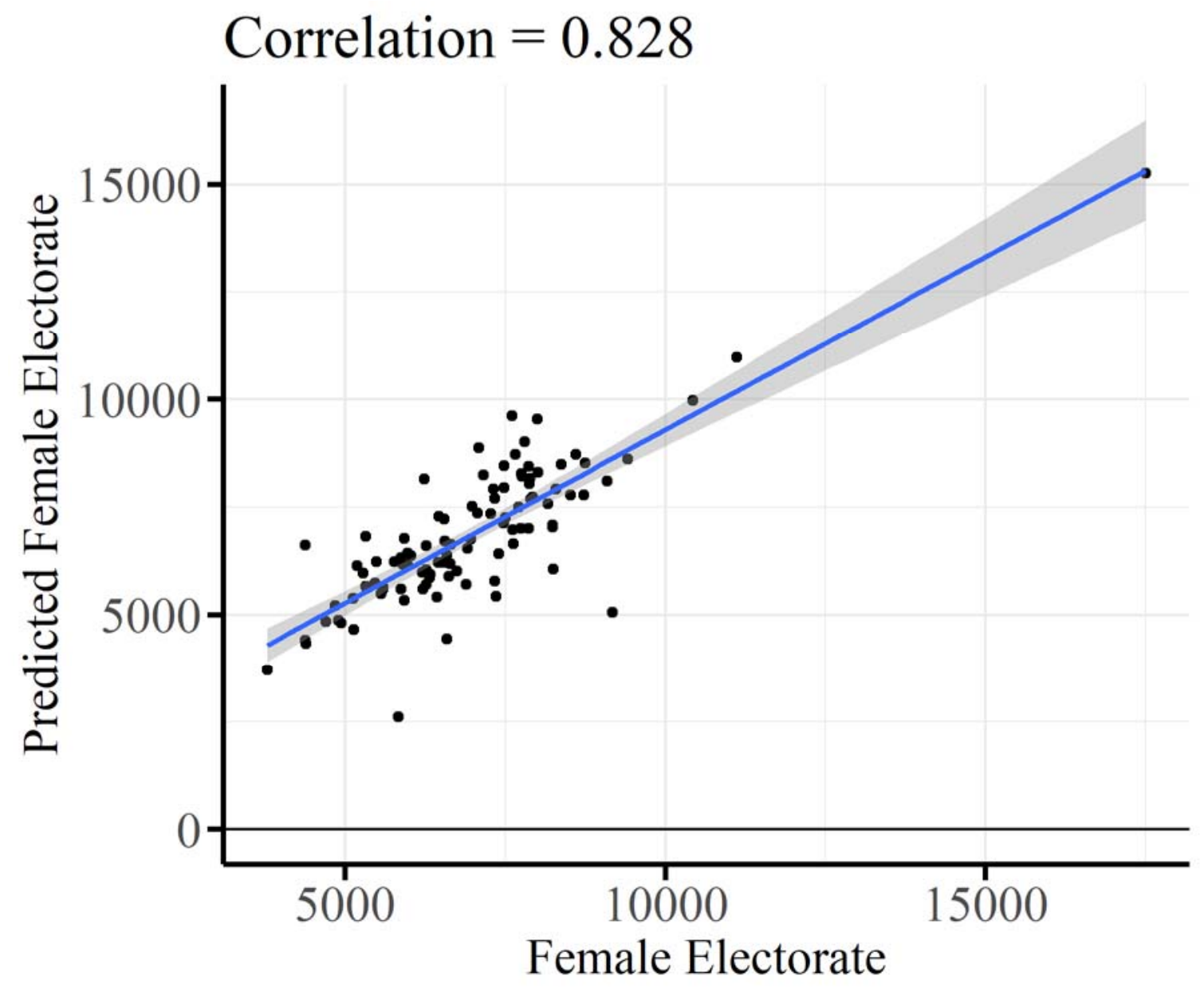




\section{Appendix}

Table A1: Machine Learning Variable Selection - Sinn Féin

\begin{tabular}{lccccc}
\hline & $\begin{array}{c}(1) \\
\text { Baseline } \\
\text { OLS }\end{array}$ & $\begin{array}{c}(2) \\
\text { Ridge } \\
\text { Regression }\end{array}$ & $\begin{array}{c}(3) \\
\text { Baseline } \\
\text { Lasso }\end{array}$ & $\begin{array}{c}\text { Square-root } \\
\text { Lasso }\end{array}$ & $\begin{array}{c}\text { Heteroskedastic } \\
\text { Lasso }\end{array}$ \\
\hline Share new males & 0.19 & 0.24 & & & -0.38 \\
Share female voters & -0.89 & -1.05 & -0.44 & -0.82 & \\
Share Ag. Labourer & -0.20 & -0.11 & & & \\
Share Urb. Labourer & 0.16 & 0.16 & & & \\
Share White Collar & -0.25 & -0.068 & & & \\
Share Skilled & -0.36 & -0.14 & & & \\
Share None/Other & 0.50 & 0.38 & & & \\
Value per acre (log) & 0.020 & 0.0076 & & & \\
1916 Deportees & 4.12 & 5.62 & & & \\
INAA Donations pc & 2.10 & 2.87 & 2.37 & 1.78 & \\
SF Candidate in prison & -0.0071 & 0.0063 & & & -0.00035 \\
Military voters & -0.34 & -0.42 & & & \\
Pop change 1841-51 & -0.0027 & -0.0020 & -0.00091 & -0.0019 & \\
Gaelic League branches & -0.019 & -0.013 & & -0.011 & 0.20 \\
Share Irish speakers & -0.063 & -0.024 & & -0.028 & 70 \\
Constant & 0.34 & 0.40 & 0.22 & 0.24 & \\
\hline Observations & 70 & 70 & 70 & 70 & \\
\hline
\end{tabular}

Table A2: Machine Learning Variable Selection - IPP

\begin{tabular}{lccccc}
\hline & $(1)$ & $(2)$ & $(3)$ & $(4)$ & $(5)$ \\
& $\begin{array}{c}\text { Baseline } \\
\text { OLS }\end{array}$ & $\begin{array}{c}\text { Ridge } \\
\text { Regression }\end{array}$ & $\begin{array}{c}\text { Baseline } \\
\text { Lasso }\end{array}$ & $\begin{array}{c}\text { Square-root } \\
\text { Lasso }\end{array}$ & $\begin{array}{c}\text { Heteroskedastic } \\
\text { Lasso }\end{array}$ \\
\hline Share new males & 0.10 & 0.29 & & 0.13 & \\
Share female voters & 0.26 & 0.038 & & & \\
Share Ag. Labourer & -0.14 & -0.0074 & & & \\
Share Urb. Labourer & 0.44 & 0.22 & & & \\
Share White Collar & 0.24 & -0.0021 & & & \\
Share Skilled & 0.36 & -0.014 & & & \\
Share None/Other & 0.069 & 0.088 & & & \\
Value per acre (log) & -0.036 & -0.0024 & & & \\
1916 Deportees & 2.41 & 1.77 & & & \\
INAA Donations pc & -1.40 & 0.90 & & & \\
SF Candidate in prison & 0.0057 & 0.0094 & & & \\
Military voters & -0.44 & 0.018 & & & \\
Pop change 1841-51 & 0.0038 & 0.0012 & & 0.0020 & \\
Gaelic League branches & 0.010 & 0.0041 & & & \\
Share Irish speakers & -0.059 & 0.018 & & & \\
Constant & -0.43 & -0.0071 & 0.016 & 0.069 & \\
\hline Observations & 70 & 70 & 70 & 70 & \\
\hline
\end{tabular}


Table A3: Machine Learning Variable Selection - Unionists

\begin{tabular}{lccccc}
\hline & $\begin{array}{c}(1) \\
\text { Baseline } \\
\text { OLS }\end{array}$ & $\begin{array}{c}(2) \\
\text { Ridge } \\
\text { Regression }\end{array}$ & $\begin{array}{c}(3) \\
\text { Baseline } \\
\text { Lasso }\end{array}$ & $\begin{array}{c}\text { Square-root } \\
\text { Lasso }\end{array}$ & $\begin{array}{c}\text { (5) } \\
\text { Heteroskedastic } \\
\text { Lasso }\end{array}$ \\
\hline Share new males & -0.35 & -0.58 & -0.32 & -0.32 & -0.14 \\
Share female voters & 0.47 & 0.94 & & & \\
Share Ag. Labourer & 0.23 & 0.099 & & & \\
Share Urb. Labourer & -0.17 & -0.30 & & & \\
Share White Collar & 0.36 & 0.17 & & & \\
Share Skilled & -0.30 & 0.081 & & & \\
Share None/Other & -0.81 & -0.45 & -0.24 & & \\
Value per acre (log) & 0.014 & -0.0043 & & & \\
1916 Deportees & -5.57 & -7.49 & -3.87 & -3.90 & \\
INAA Donations pc & -0.64 & -3.37 & & & \\
SF Candidate in prison & 0.0069 & -0.012 & & & \\
Military voters & 1.20 & 0.50 & & & \\
Pop change 1841-51 & -0.0011 & 0.00016 & & & \\
Gaelic League branches & 0.011 & 0.0053 & 0.0023 & 0.0024 & \\
Share Irish speakers & 0.15 & -0.020 & 0.038 & 0.039 & \\
Constant & 0.18 & -0.12 & 0.56 & 0.56 & \\
\hline Observations & 70 & 70 & 70 & 70 & \\
\hline
\end{tabular}

Table A4: Machine Learning Variable Selection - Non-voting

\begin{tabular}{|c|c|c|c|c|c|}
\hline & $\begin{array}{c}(1) \\
\text { Baseline } \\
\text { OLS }\end{array}$ & $\begin{array}{c}(2) \\
\text { Ridge } \\
\text { Regression }\end{array}$ & $\begin{array}{c}(3) \\
\text { Baseline } \\
\text { Lasso } \\
\end{array}$ & $\begin{array}{c}(4) \\
\text { Square-root } \\
\text { Lasso } \\
\end{array}$ & $\begin{array}{c}\text { (5) } \\
\text { Heteroskedastic } \\
\text { Lasso } \\
\end{array}$ \\
\hline Share new males & -0.18 & 0.0015 & & & \\
\hline Share female voters & 1.18 & 0.0092 & & 0.94 & \\
\hline Female literacy rate & -0.39 & -0.011 & & -0.34 & \\
\hline Female participation rate & -0.91 & -0.030 & & -0.87 & \\
\hline Value per acre (log) & -0.0095 & -0.000089 & & -0.0024 & \\
\hline Suffrage societies per km & -0.13 & 0.0041 & & -0.027 & \\
\hline Suffrage activity per km & -1.37 & -0.027 & & -1.09 & \\
\hline Flu rate & 0.017 & 0.000020 & & 0.014 & \\
\hline Ruggedness & -0.0016 & -0.000011 & & -0.00090 & \\
\hline Train stations & 0.00044 & -0.000012 & & 0.00031 & \\
\hline Rainfall Dec 1918 & 0.00033 & 0.000014 & & & \\
\hline Constant & 0.43 & 0.30 & 0.30 & 0.24 & 0.30 \\
\hline Observations & 75 & 75 & 75 & 75 & 75 \\
\hline
\end{tabular}


TABLE A5: Understanding where Sinn Féin was unopposed

\begin{tabular}{|c|c|c|c|c|c|c|}
\hline & \multicolumn{6}{|c|}{ Dependent variable: } \\
\hline & \multicolumn{6}{|c|}{ SF Unopposed } \\
\hline & $\begin{array}{c}\text { Franchise } \\
\text { (1) }\end{array}$ & $\begin{array}{c}\text { Economic } \\
\text { (2) }\end{array}$ & $\begin{array}{c}1916 \text { Opinion } \\
\text { (3) }\end{array}$ & $\begin{array}{c}1918 \text { Opinion } \\
\text { (4) }\end{array}$ & $\begin{array}{l}\text { Long Run } \\
\text { (5) }\end{array}$ & $\begin{array}{l}\text { All } \\
(6)\end{array}$ \\
\hline Share new males & $\begin{array}{l}-0.010 \\
(0.013)\end{array}$ & & & & & $\begin{array}{l}-0.006 \\
(0.012)\end{array}$ \\
\hline Share female electors & $\begin{array}{l}-0.050 \\
(0.043)\end{array}$ & & & & & $\begin{array}{c}0.001 \\
(0.030)\end{array}$ \\
\hline Share Ag. Labourer & & $\begin{array}{c}0.051 \\
(0.059)\end{array}$ & & & & $\begin{array}{c}0.046 \\
(0.035)\end{array}$ \\
\hline Share Urb. Labourer & & $\begin{array}{l}-0.059 \\
(0.087)\end{array}$ & & & & $\begin{array}{l}-0.066 \\
(0.080)\end{array}$ \\
\hline Share White Collar & & $\begin{array}{c}0.023 \\
(0.085)\end{array}$ & & & & $\begin{array}{c}0.042 \\
(0.063)\end{array}$ \\
\hline Share Skilled & & $\begin{array}{c}0.037 \\
(0.155)\end{array}$ & & & & $\begin{array}{c}0.077 \\
(0.140)\end{array}$ \\
\hline Share None/Other & & $\begin{array}{l}-0.017 \\
(0.091)\end{array}$ & & & & $\begin{array}{c}0.027 \\
(0.031)\end{array}$ \\
\hline Value per acre (log) & & $\begin{array}{l}-0.026 \\
(0.075)\end{array}$ & & & & $\begin{array}{l}-0.012 \\
(0.084)\end{array}$ \\
\hline 1916 Deportees pc & & & $\begin{array}{l}-0.081 \\
(0.059)\end{array}$ & & & $\begin{array}{c}-0.046 \\
(0.050)\end{array}$ \\
\hline INAA Donations pc & & & $\begin{array}{c}0.047 \\
(0.032)\end{array}$ & & & $\begin{array}{c}0.013 \\
(0.016)\end{array}$ \\
\hline SF Candidate in prison & & & & $\begin{array}{l}0.0002 \\
(0.054)\end{array}$ & & $\begin{array}{l}-0.008 \\
(0.034)\end{array}$ \\
\hline Military voters & & & & $\begin{array}{c}-0.068 \\
(0.061)\end{array}$ & & $\begin{array}{l}-0.001 \\
(0.043)\end{array}$ \\
\hline Pop change 1841-51 & & & & & $\begin{array}{l}-0.141 \\
(0.089)\end{array}$ & $\begin{array}{l}-0.088 \\
(0.055)\end{array}$ \\
\hline Gaelic League branches & & & & & $\begin{array}{c}-0.004 \\
(0.020)\end{array}$ & $\begin{array}{l}-0.006 \\
(0.013)\end{array}$ \\
\hline Share Irish speakers & & & & & $\begin{array}{l}-0.039 \\
(0.040)\end{array}$ & $\begin{array}{l}-0.010 \\
(0.019)\end{array}$ \\
\hline Baseline Controls & Yes & Yes & Yes & Yes & Yes & Yes \\
\hline Observations & 100 & 100 & 100 & 100 & 100 & 100 \\
\hline
\end{tabular}

Logit regression marginal effects. All explanatory variables are standardised using the Z-score transformation. Cluster robust standard errors in parentheses. All regressions include a constant. Baseline Controls: Share Catholic, Average Age, mean and standard deviation of Household Size. ${ }^{* *} \mathrm{p}<0.01,{ }^{* *} \mathrm{p}<0.05,{ }^{*} \mathrm{p}<0.1$ 
Table A6: Seemingly Unrelated Regressions - Franchise

\begin{tabular}{cccc}
\multicolumn{4}{c}{ Vote Shares } \\
\hline SF & IPP & Unionist & Non-voting \\
$(1)$ & $(2)$ & $(3)$ & $(4)$ \\
\hline-0.008 & 0.023 & $-0.016^{* *}$ & 0.002 \\
$(0.014)$ & $(0.017)$ & $(0.008)$ & $(0.012)$ \\
$-0.042^{*}$ & 0.025 & -0.014 & 0.031 \\
$(0.025)$ & $(0.025)$ & $(0.010)$ & $(0.021)$ \\
Yes & Yes & Yes & Yes \\
75 & 75 & 75 & 75 \\
0.714 & 0.409 & 0.937 & 0.135 \\
\hline
\end{tabular}

Restricted SUR regressions. All explanatory variables are standardised using the Z-score transformation. Cluster bootstrap standard errors in parentheses. All regressions include a constant. Baseline Controls: Share Catholic, Turnout, Average Age, mean and standard deviation of Household Size. ${ }^{* * *} \mathrm{p}<0.01,{ }^{* *} \mathrm{p}<0.05,{ }^{*} \mathrm{p}<0.1$ 
Table A7: Seemingly Unrelated Regressions - Economic

\begin{tabular}{lcccc}
\hline & \multicolumn{4}{c}{ Vote Shares } \\
\cline { 2 - 5 } & SF & IPP & Unionist & Non-voting \\
& $(1)$ & $(2)$ & $(3)$ & $(4)$ \\
\hline Share Ag. Labourer & 0.007 & -0.005 & $0.031^{* *}$ & -0.034 \\
Share Urb. Labourer & $(0.031)$ & $(0.032)$ & $(0.014)$ & $(0.027)$ \\
Share White Collar & -0.009 & 0.042 & -0.017 & -0.015 \\
& $(0.037)$ & $(0.033)$ & $(0.023)$ & $(0.027)$ \\
Share Skilled & -0.039 & 0.061 & 0.034 & -0.055 \\
Share None/Other & $(0.065)$ & $(0.056)$ & $(0.028)$ & $(0.055)$ \\
& $-0.110^{*}$ & $0.102^{*}$ & 0.046 & -0.038 \\
Value per acre (log) & $(0.066)$ & $(0.060)$ & $(0.051)$ & $(0.066)$ \\
& 0.022 & -0.004 & $-0.037^{*}$ & 0.020 \\
\hline Baseline Controls & $(0.030)$ & $(0.032)$ & $(0.019)$ & $(0.030)$ \\
Observations & 0.036 & -0.062 & 0.030 & -0.004 \\
$\mathrm{R}^{2}$ & $(0.043)$ & $(0.046)$ & $(0.033)$ & $(0.039)$ \\
\hline Res & Yes & Yes & Yes & Yes \\
\hline
\end{tabular}

Restricted SUR regressions. All explanatory variables are standardised using the Z-score transformation. Cluster bootstrap standard errors in parentheses. All regressions include a constant. Baseline Controls: Share Catholic, Turnout, Average Age, mean and standard deviation of Household Size. ${ }^{* * *} \mathrm{p}<0.01,{ }^{* *} \mathrm{p}<0.05,{ }^{*} \mathrm{p}<0.1$ 
Table A8: Seemingly Unrelated Regressions - 1916 Opinion

Vote Shares

\begin{tabular}{lcccc} 
& \multicolumn{4}{c}{ Vote Shares } \\
\cline { 2 - 5 } & SF & IPP & Unionist & Non-voting \\
& $(1)$ & $(2)$ & $(3)$ & $(4)$ \\
\hline 1916 Deportees pc & 0.012 & -0.003 & -0.021 & 0.012 \\
INAA Donations pc & $(0.030)$ & $(0.038)$ & $(0.023)$ & $(0.026)$ \\
& $0.033^{* *}$ & -0.010 & 0.001 & $-0.024^{*}$ \\
\hline Baseline Controls & $(0.015)$ & $(0.017)$ & $(0.009)$ & $(0.013)$ \\
Observations & Yes & Yes & Yes & Yes \\
$\mathrm{R}^{2}$ & 75 & 75 & 75 & 75 \\
\hline
\end{tabular}

Restricted SUR regressions. All explanatory variables are standardised using the Z-score transformation. Cluster bootstrap standard errors in parentheses. All regressions include a constant. Baseline Controls: Share Catholic, Turnout, Average Age, mean and standard deviation of Household Size. ${ }^{* * *} \mathrm{p}<0.01,{ }^{* *} \mathrm{p}<0.05$, ${ }^{*} \mathrm{p}<0.1$ 
Table A9: Seemingly Unrelated Regressions - 1918 Opinion

\begin{tabular}{lcccc}
\hline & \multicolumn{4}{c}{ Vote Shares } \\
\cline { 2 - 5 } & SF & IPP & Unionist & Non-voting \\
& $(1)$ & $(2)$ & $(3)$ & $(4)$ \\
\hline SF Candidate in prison & -0.010 & $0.024^{*}$ & 0.004 & $-0.018^{*}$ \\
Military voters & $(0.015)$ & $(0.014)$ & $(0.009)$ & $(0.010)$ \\
& $-0.042^{*}$ & $0.044^{*}$ & 0.014 & -0.016 \\
Baseline Controls & $(0.023)$ & $(0.023)$ & $(0.018)$ & $(0.024)$ \\
Observations & Yes & Yes & Yes & Yes \\
$\mathrm{R}^{2}$ & 75 & 75 & 75 & 75 \\
\hline Restricted SUR regres & 0.704 & 0.433 & 0.935 & 0.120 \\
\hline
\end{tabular}

Restricted SUR regressions. All explanatory variables are standardised using the Z-score transformation. Cluster bootstrap standard errors in parentheses. All regressions include a constant. Baseline Controls: Share Catholic, Turnout, Average Age, mean and standard deviation of Household Size. ${ }^{* * *} \mathrm{p}<0.01,{ }^{* *} \mathrm{p}<0.05,{ }^{*} \mathrm{p}<0.1$ 
Table A10: Seemingly Unrelated Regressions - Long Run

\begin{tabular}{lcccc}
\hline & \multicolumn{4}{c}{ Vote Shares } \\
\cline { 2 - 5 } & SF & IPP & Unionist & Non-voting \\
& $(1)$ & $(2)$ & $(3)$ & $(4)$ \\
\hline Pop change 1841-51 & $-0.087^{* *}$ & $0.085^{* *}$ & -0.017 & 0.019 \\
Gaelic League branches & $(0.034)$ & $(0.034)$ & $(0.020)$ & $(0.032)$ \\
& $-0.038^{* *}$ & 0.020 & 0.010 & 0.008 \\
Share Irish speakers & $(0.015)$ & $(0.016)$ & $(0.010)$ & $(0.014)$ \\
& -0.019 & -0.024 & -0.003 & $0.046^{*}$ \\
Baseline Controls & $(0.027)$ & $(0.022)$ & $(0.017)$ & $(0.025)$ \\
Observations & Yes & Yes & Yes & Yes \\
$\mathrm{R}^{2}$ & 75 & 75 & 75 & 75 \\
\hline
\end{tabular}

Restricted SUR regressions. All explanatory variables are standardised using the Z-score transformation. Cluster bootstrap standard errors in parentheses. All regressions include a constant. Baseline Controls: Share Catholic, Turnout, Average Age, mean and standard deviation of Household Size. ${ }^{* * *} \mathrm{p}<0.01,{ }^{* *} \mathrm{p}<0.05,{ }^{*} \mathrm{p}<0.1$ 
Table A11: Seemingly Unrelated Regressions - All

\begin{tabular}{|c|c|c|c|c|}
\hline & \multicolumn{4}{|c|}{ Vote Shares } \\
\hline & $\begin{array}{l}\text { SF } \\
(1)\end{array}$ & $\begin{array}{l}\text { IPP } \\
(2)\end{array}$ & $\begin{array}{l}\text { Unionist } \\
\text { (3) }\end{array}$ & $\begin{array}{c}\text { Non-voting } \\
\text { (4) }\end{array}$ \\
\hline Share new males & $\begin{array}{l}-0.001 \\
(0.031)\end{array}$ & $\begin{array}{c}0.010 \\
(0.036)\end{array}$ & $\begin{array}{c}-0.013 \\
(0.014)\end{array}$ & $\begin{array}{c}0.005 \\
(0.020)\end{array}$ \\
\hline Share female electors & $\begin{array}{l}-0.029 \\
(0.033)\end{array}$ & $\begin{array}{l}-0.012 \\
(0.037)\end{array}$ & $\begin{array}{l}-0.010 \\
(0.022)\end{array}$ & $\begin{array}{c}0.051^{*} \\
(0.030)\end{array}$ \\
\hline Share Ag. Labourer & $\begin{array}{l}0.0003 \\
(0.041)\end{array}$ & $\begin{array}{l}-0.015 \\
(0.038)\end{array}$ & $\begin{array}{c}0.033^{*} \\
(0.020)\end{array}$ & $\begin{array}{l}-0.019 \\
(0.036)\end{array}$ \\
\hline Share Urb. Labourer & $\begin{array}{c}0.010 \\
(0.048)\end{array}$ & $\begin{array}{c}0.037 \\
(0.050)\end{array}$ & $\begin{array}{c}-0.038 \\
(0.026)\end{array}$ & $\begin{array}{l}-0.009 \\
(0.034)\end{array}$ \\
\hline Share White Collar & $\begin{array}{l}-0.023 \\
(0.066)\end{array}$ & $\begin{array}{c}0.063 \\
(0.066)\end{array}$ & $\begin{array}{c}0.035 \\
(0.044)\end{array}$ & $\begin{array}{l}-0.075 \\
(0.068)\end{array}$ \\
\hline Share Skilled & $\begin{array}{l}-0.029 \\
(0.097)\end{array}$ & $\begin{array}{c}0.057 \\
(0.089)\end{array}$ & $\begin{array}{c}0.022 \\
(0.077)\end{array}$ & $\begin{array}{l}-0.049 \\
(0.099)\end{array}$ \\
\hline Share None/Other & $\begin{array}{c}0.039 \\
(0.031)\end{array}$ & $\begin{array}{l}-0.021 \\
(0.045)\end{array}$ & $\begin{array}{c}-0.032 \\
(0.026)\end{array}$ & $\begin{array}{c}0.013 \\
(0.030)\end{array}$ \\
\hline Value per acre (log) & $\begin{array}{c}0.045 \\
(0.067)\end{array}$ & $\begin{array}{l}-0.082 \\
(0.062)\end{array}$ & $\begin{array}{c}0.045 \\
(0.043)\end{array}$ & $\begin{array}{l}-0.008 \\
(0.060)\end{array}$ \\
\hline 1916 Deportees pc & $\begin{array}{c}0.009 \\
(0.053)\end{array}$ & $\begin{array}{c}0.005 \\
(0.052)\end{array}$ & $\begin{array}{c}-0.021 \\
(0.033)\end{array}$ & $\begin{array}{c}0.008 \\
(0.045)\end{array}$ \\
\hline INAA Donations pc & $\begin{array}{c}0.014 \\
(0.023)\end{array}$ & $\begin{array}{l}-0.005 \\
(0.024)\end{array}$ & $\begin{array}{c}-0.001 \\
(0.014)\end{array}$ & $\begin{array}{l}-0.008 \\
(0.025)\end{array}$ \\
\hline SF Candidate in prison & $\begin{array}{l}-0.015 \\
(0.020)\end{array}$ & $\begin{array}{c}0.027 \\
(0.019)\end{array}$ & $\begin{array}{c}0.011 \\
(0.011)\end{array}$ & $\begin{array}{l}-0.023 \\
(0.016)\end{array}$ \\
\hline Military voters & $\begin{array}{l}-0.031 \\
(0.053)\end{array}$ & $\begin{array}{c}0.011 \\
(0.052)\end{array}$ & $\begin{array}{c}0.044 \\
(0.032)\end{array}$ & $\begin{array}{l}-0.024 \\
(0.051)\end{array}$ \\
\hline Pop change 1841-51 & $\begin{array}{l}-0.083^{* *} \\
(0.042)\end{array}$ & $\begin{array}{l}0.091^{* *} \\
(0.037)\end{array}$ & $\begin{array}{c}-0.025 \\
(0.032)\end{array}$ & $\begin{array}{c}0.017 \\
(0.045)\end{array}$ \\
\hline Gaelic League branches & $\begin{array}{l}-0.038^{* *} \\
(0.019)\end{array}$ & $\begin{array}{c}0.020 \\
(0.018)\end{array}$ & $\begin{array}{c}0.011 \\
(0.012)\end{array}$ & $\begin{array}{c}0.008 \\
(0.018)\end{array}$ \\
\hline Share Irish speakers & $\begin{array}{l}-0.021 \\
(0.046)\end{array}$ & $\begin{array}{l}-0.013 \\
(0.039)\end{array}$ & $\begin{array}{c}0.017 \\
(0.026)\end{array}$ & $\begin{array}{c}0.018 \\
(0.037)\end{array}$ \\
\hline Baseline Controls & Yes & Yes & Yes & Yes \\
\hline Observations & 75 & 75 & 75 & 75 \\
\hline $\mathrm{R}^{2}$ & 0.818 & 0.591 & 0.960 & 0.361 \\
\hline
\end{tabular}

Restricted SUR regressions. All explanatory variables are standardised using the Z-score transformation. Cluster bootstrap standard errors in parentheses. All regressions include a constant. Baseline Controls: Share Catholic, Turnout, Average Age, mean and standard deviation of Household Size. ${ }^{* * *} \mathrm{p}<0.01,{ }^{* *} \mathrm{p}<0.05$, ${ }^{*} \mathrm{p}<0.1$ 


\section{$\underline{\text { Variable Descriptions }}$}

Sinn Féin vote - Votes cast for Sinn Féin as a share of total parliamentary electorate (ARK Northern Ireland Elections database https://www.ark.ac.uk/elections/).

IPP vote - Votes cast for Irish Parliamentary Party (including Independent Nationalists) as a share of total parliamentary electorate (ARK Northern Ireland Elections database https://www.ark.ac.uk/elections/).

Unionist vote - Votes cast for Unionist Parties (Ulster Unionists, Independent Unionists and Labour Unionists) as a share of total parliamentary electorate (ARK Northern Ireland Elections database https://www.ark.ac.uk/elections/).

Non-vote - Non-voters as a share of total parliamentary electorate (ARK Northern Ireland Elections database https://www.ark.ac.uk/elections/).

Share female electors - Female parliamentary electors as a share of total parliamentary electorate (UK Parliament, 1918).

Share new males -Male local electors as a share of total parliamentary electorate (UK Parliament, 1918).

Occupation Shares -Uses the HISCO codes originally created by Fernihough, Ó Gráda, and Walsh (2015) which are then categorised as a HISCLASS codes. The HISCLASS coding scheme is then further matched to the occupational classifications used in Connor (2019).

Share Catholic - Catholics as a share of population over 21 years of age (1911 Census of Ireland).

Turnout - Total votes cast as a share of total parliamentary electorate (ARK Northern Ireland Elections database https://www.ark.ac.uk/elections/). 
SF unopposed - Equals one if Sinn Féin were unopposed in a constituency, zero otherwise (ARK Northern Ireland Elections database https://www.ark.ac.uk/elections/).

SF no contest - Equals one if Sinn Féin did not contest election in a constituency, zero otherwise (ARK Northern Ireland Elections database https://www.ark.ac.uk/elections/).

Population density (log) - Natural log of population per square kilometre (1911 Census of Ireland).

Average age - Average of population (1911 Census of Ireland).

Value per acre - Total valuation of constituency divided by acres (1911 Census of Ireland).

Pop change 1841-51 - Median population change (per cent) for all civil parish data lying within 1918 constituency boundaries. Civil parish data as in Fernihough and Ó Gráda (2018).

Gaelic League branches - Number of Gaelic League Branches in a constituency (data kindly provided by Dr. Eoin McLaughlin)

SF Candidate in prison - Equals one if Sinn Féin candidate was imprisoned at time of election, zero otherwise (Travers, 2017).

Military voters - Military parliamentary electors as a share of total parliamentary electorate (UK Parliament, 1918).

INAA Donations pc - Total value of donations to the INAAVDF scaled by population (source: see text)

1916 Deportees pc - Number of prisoners deported in the aftermath of 1916 Rising divided by population (Murphy, 2017).

Share Irish speakers - Irish language speakers as a share of population (1911 Census of Ireland). 
Suffrage societies per $\mathbf{k m}$ - Number of suffrage society branches in constituency in 1913 scaled by area (Ward, 2017).

Suffrage activity per $\mathbf{k m}$-Count of incidents of suffrage activities in constituency in 1913 scaled by area (Ward, 2017).

Female literacy rate - Literate females as share of female population aged over 21 (1911 Census of Ireland).

Female participation rate - Employed females as share of female population aged over 21 (1911 Census of Ireland).

Flu rate - Deaths from influenza and pneumonia in 1918 per 1000 population calculated at the constituency level from Poor Law Union data in Annual Report of the Registrar-General for Ireland, 1919.

Ruggedness - Terrain Ruggedness Index created from a raster dataset of altitude which calculates the mean of the absolute differences between the altitude in each cell and the surrounding 8 cells. The constituency-level variable was created by taking the median of the index of all raster cells within the parliamentary constituency boundaries (see Wilson et al., 2007)

Train stations - Number of stations operating in constituency in 1918. Data digitised from Johnson (1997).

Rainfall Dec 1918 - Total Rainfall in December 1918 (in mm) calculated at the constituency level based on UK metrological Office data Mill and Salter (1919). 


\section{Appendix II: Matching of Electoral Divisions to Parliamentary Constituencies - Ireland,}

1918

The objective of this exercise was to link DEDs (District Electoral Divisions) from the 1911 census to parliamentary constituencies of the 1918 election. The exercise used two sources to identify which DEDs should correspond to which parliamentary constituencies based on whether the constituency boundaries were altered in 1917 from the previous boundaries set in 1885.

\section{Part I (Counties \& Boroughs in 1917 Boundary Commission volume):}

Down, Dublin County, Galway, Kilkenny, Tyrone, Waterford, Borough of Belfast, and Borough of Dublin.

N.B. Carlow, King's County (Offaly), Leitrim, Longford, Louth, Queen's County (Laois) and Westmeath each constituted their own constituency so these constituencies were unambiguous.

1. Name of DED was found in index of DEDs in "General Topographical Index, Ireland, 1901" and the number(s) in the final column "No. in Table VII of Census County Book 1901" as well as County District was recorded. Link: https://archive.org/stream/op1254784-1001\#page/n993/mode/2up.

2. Located county entry and list of Districts included in each parliamentary constituency (and/or map) and recorded which Parliamentary constituency each district was in. "Representation of the People Bill 1917: redistribution of seats: report" Link: http://www.dippam.ac.uk/eppi/documents/22430 


\section{Part II (counties not in 1917 Boundary Commission volume):}

1. Name of DED was found in index of DEDs in "General Topographical Index, Ireland, 1901" and the number(s) in the final column "No. in Table VII of Census County Book 1901" as well as County District was recorded. Link: https://archive.org/stream/op1254784-1001\#page/n993/mode/2up._This was completed for each county at a time.

2. Once a county is complete, county is located in "Area, Houses and population, Ireland, 1901" (there is a volume for each province) Link: http://www.histpop.org/ohpr/servlet/Browse?path=Browse/Census\%20(by\%20geogra phy)/Ireland $/ 1901 \&$ active $=$ yes $\&$ titlepos $=0$

From table VII, each DED is matched to the corresponding Barony (i.e. 73. Carnmoon (DED) $=$ Dunluce Lower (Barony).

3. Using "Baronies and Electoral Constituencies (1885)" Link: https://parlipapers.proquest.com/parlipapers/result/pqpdocumentview?accountid=133 74\&groupid=98693\&pgId=f3e7d86b-ca19-4dca-b840-e5c8d8b655bb, county entry was located with list of Baronies and/or map. The Parliamentary constituency each Barony was in was then recorded.

General Notes:

- When a DED was listed as being in more than one Barony, both were recorded (e.g. Belfast Lower, Belfast Upper) in order or area. DED then assigned to a parliamentary constituency based on first named Barony (unless it is obvious otherwise from constituency description). 